\title{
Multifunctional Luminescent and Proton-Conducting Lanthanide Carboxyphosphonate Open-Framework Hybrids Exhibiting Crystalline-to-Amorphous-to-Crystalline Transformations
}

\author{
Rosario M. P. Colodrero, ${ }^{\dagger}$ Konstantinos E. Papathanasiou, ${ }^{\ddagger}$ Nikoleta Stavgianoudaki, ${ }^{\ddagger}$
}

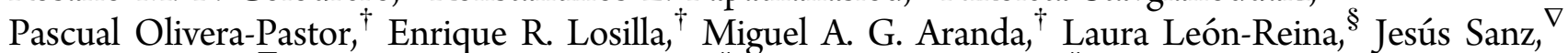
Isabel Sobrados, ${ }^{\nabla}$ Duane Choquesillo-Lazarte, ${ }^{\#}$ Juan M. García-Ruiz, ${ }^{\#}$ Pedro Atienzar, ${ }^{\circ}$ Fernando Rey, $^{\bigcirc}$ Konstantinos D. Demadis, ${ }^{* *+}$ and Aurelio Cabeza $* \dagger$

${ }^{\dagger}$ Departamento de Química Inorgánica, Universidad de Málaga, Campus Teatinos s/n, Málaga 29071, Spain

${ }^{\ddagger}$ Crystal Engineering, Growth and Design Laboratory, Department of Chemistry, University of Crete, Voutes Campus, Crete, GR-71003, Greece

${ }^{\S}$ Servicios Centrales de Apoyo a la Investigación, SCAI, Universidad de Málaga, Campus Teatinos s/n, 29071 Málaga, Spain

$\nabla$ Instituto de Ciencia de Materiales, CSIC, Cantoblanco, 28049 Madrid, Spain

\#Laboratorio de Estudios Crystalográficos, IACT-CSIC, Granada, Spain

OInstituto de Tecnología Química (UPV-CSIC), Avenida de los Naranjos s/n, 46022 Valencia, Spain

Supporting Information

ABSTRACT: The chemistry of metal phosphonates has been progressing fast with the addition of new materials that possess novel structural features and new properties, occasionally in a cooperative manner. In this paper, we report a new family of functional lanthanide-carboxyphosphonate materials. Specifically, the lanthanide is $\mathrm{La}, \mathrm{Ce}, \mathrm{Pr}, \mathrm{Sm}, \mathrm{Eu}, \mathrm{Gd}, \mathrm{Tb}$, or $\mathrm{Dy}$ and the carboxyphosphonate ligand is 2-hydroxyphosphonoacetic acid $\left(\mathrm{H}_{3} \mathrm{HPA}\right)$. All reported LnHPA compounds, $\mathrm{Ln}_{3}\left(\mathrm{H}_{0.75} \mathrm{O}_{3} \mathrm{PCHOHCOO}\right)_{4} \cdot x \mathrm{H}_{2} \mathrm{O}(x=15-16)$, crystallize in the orthorhombic system. Two types of structures were isolated: series I and II polymorphs. For both series, the three-dimensional (3D)
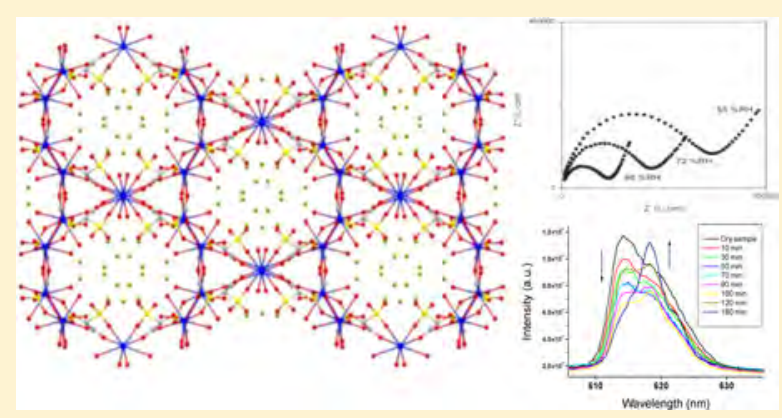
open frameworks result from the linkage of similar organo-inorganic layers, in the ac-plane, by central lanthanide cations, which yield trimeric units also found in other metal-HPA hybrids. Large oval-shaped $1 \mathrm{D}$ channels are formed by the spatial separation of the layers along the $b$-axis and filled with lattice water molecules. LnHPA materials undergo remarkable crystalline-to-amorphous-to crystalline transformations upon dehydration and rehydration cycles, as confirmed by thermodiffraction and NMR spectroscopy. The highest proton conductivity was observed for GdHPA (series II), $3.2 \times 10^{-4} \mathrm{~S} \mathrm{~cm}^{-1}$ at $98 \% \mathrm{RH}$ and $T=21{ }^{\circ} \mathrm{C}$. The dehydration-rehydration chemistry was also followed by photoluminescence spectroscopy. It was shown that loss and reuptake of water molecules are accompanied by clear changes in the photoluminescence spectra and lifetimes of the Eu analog (series II). Our present results reveal a wide family of wellcharacterized, multifunctional lanthanide-based phosphonate 3D-structured metal-organic frameworks (MOFs) that show reversible crystalline-to-amorphous-to-crystalline transformations and, at the same time, exhibit high proton conductivity.

KEYWORDS: lanthanide, phosphonate, luminescence, MOF, 3D structure, reversible transformation, proton conductivity

\section{INTRODUCTION}

The field of metal-organic framework (MOF) materials has skyrocketed during the last 10 years, principally because of two reasons: (a) the increasing appearance of a milieu of new structural motifs, ${ }^{1}$ and (b) the enormous functionality of such materials. ${ }^{2}$ In particular, lanthanide metal-organic frameworks (Ln-MOFs) are presently receiving growing attention, because of their potential applications in fields such as gas adsorption, ${ }^{3}$ magnetism, ${ }^{4}$ and catalysis, ${ }^{5}$ and especially for their photoluminescence properties. ${ }^{6}$ Ln-MOFs are very promising as multifunctional luminescent materials, because both the inorganic and organic moieties can provide suitable platforms to generate luminescence. Moreover, metal-ligand charge transfer and/or the presence of guest molecules within porous MOFs can potentially generate and tailor the luminescence properties. ${ }^{7}$ Multifunctional Ln-MOFs are usually based on, but

Received: July 27, 2012

Revised: September 13, 2012

Published: September 15, 2012 
not restricted to, a combination of photoluminescence and some other additional properties.

The adjustable structures and properties of MOFs, together with the rich coordination chemistry and functionality of the rare-earth ions, should constitute an important advantage over other candidate classes for a variety of solid-state applications such as chemo-sensory materials, ${ }^{8}$ light-emitting materials, ${ }^{9}$ or proton conductors. ${ }^{10} \mathrm{~A}$ multitude of organic linkers, such as carboxylates, phosphonates, or sulfonates, have been utilized to construct lanthanide MOFs. Multichelate phosphonate ligands are "alternative" organic linkers (to the widespread polycarboxylates) and allow access to a variety of thermally and chemically stable MOFs. ${ }^{11}$ Such architectures have also been reported for Ln-MOFs. ${ }^{12}$ However, control over the dimensionality of phosphonate-based Ln-MOFs still remains an unconquered challenge.

Recently, phosphonoacetic acid has been employed in synthetic efforts, giving rise to a series of isostructural twodimensional (2D) layered lanthanide phosphonates, by employing hydrothermal conditions and lanthanide nitrates as the Ln source. ${ }^{13}$ By using a closely related inexpensive ligand, 2hydroxyphosphonoacetic acid $\left(\mathrm{H}_{3} \mathrm{HPA}\right)$, we have recently synthesized $2 \mathrm{D}$ and $3 \mathrm{D}$ Ca-MOFs. ${ }^{14}$ The main structural feature of these compounds is that the frameworks are constructed from trimeric Ca-HPA-Ca-HPA-Ca secondary building units (SBUs) interconnected through phosphonate/ carboxylate moeties. The trimeric SBU could even be isolated as a "stand-alone" species at neutral $\mathrm{pH}^{15}$ Furthermore, $\mathrm{Cd}^{2+}$ derivatives were found to follow a close pattern of crystallization, indicating that this trimeric unit may be a common structural "brick" of a variety of $2 \mathrm{D}$ and 3D metal frameworks, within a wide range of ionic radii. ${ }^{16}$ Previous studies carried out with divalent metal phosphonoacetates showed that synthesis at room temperature favors the formation of solids of low dimensionality, $1 \mathrm{D}$ or $2 \mathrm{D} .{ }^{17,18}$ The preparation of solids with tridimensional frameworks usually requires hydrothermal/solvothermal conditions. ${ }^{19}$

Within the field of metal phosphonates, elegant efforts have been put forth for access to suitable proton-conducting materials. ${ }^{10 \mathrm{~b}}$ For a material to be proton-conductive, it needs to contain acidic protons and must have an appropriate framework that facilitates charge transport. In the case of metal phosphonates, the role of acidic groups is played by the phosphonic acid (or partially protonated phosphonate) groups. In such crystalline structural architectures, highly ordered phosphonate groups in close proximity with lattice water molecules create pathways that could yield proton conductors.

In the present work, we report two series of lanthanide openframework hybrids based on $\mathrm{H}_{3} \mathrm{HPA}$. These materials were obtained by slow crystallization at ambient conditions from very acidic aqueous solutions. They possess high water content (both Ln-coordinated and in the lattice), they exhibit the aforementioned trimeric SBU structural feature, and importantly, they form water-filled 1D channels. The most remarkable attributes of these hybrids are high proton conductivity, water-content-dependent photoluminescence and remarkable crystalline-to-amorphous-to-crystalline transformations.

\section{EXPERIMENTAL SECTION}

Materials. All starting materials were obtained from commercial sources and used as-received. Deionized (DI) water was used for all syntheses. The lanthanide ( $\mathrm{Ln}=\mathrm{La}, \mathrm{Ce}, \mathrm{Pr}, \mathrm{Sm}, \mathrm{Eu}, \mathrm{Gd}, \mathrm{Tb}$, and $\mathrm{Dy}$ ) nitrate hexahydrate salts (99.5\%), were from Alfa, USA. Sodium alginate was from Aldrich, USA. $\mathrm{H}_{3} \mathrm{HPA}$ ( $60 \%$ aqueous solution) was from Biolabs, UK. The $\mathrm{pH}$ meter used was a wTw $\mathrm{pH} 315 \mathrm{i}$ setup, equipped with a SeTix 41 electrode. Elemental analyses $(\mathrm{C}, \mathrm{H}, \mathrm{N})$ were measured on a Perkin-Elmer Model 240 analyzer. Infrared spectra were collected in a FTIR Nicolet 5DXC spectrometer. All spectra were recorded in the $4000-400 \mathrm{~cm}^{-1}$ range at $4 \mathrm{~cm}^{-1}$ resolution, and 50 scans were accumulated. In situ surface infrared spectra for one sample, was collected by diffuse-reflectance infrared Fourier transform spectroscopy (DRIFTS), using a Varian 3100 FTIR spectrometer. A Harrick Scientific Praying Mantis equipped with a high-temperature reaction chamber was mounted inside the spectrometer. Measurements were carried out between room temperature and $190{ }^{\circ} \mathrm{C}$. The background spectrum was recorded with $\mathrm{KBr}$ purged with a $50 \mathrm{~mL} \mathrm{~min}{ }^{-1} \mathrm{He}$ flow. The DRIFTS spectra of adsorbed species were measured under a He flow in the $4000-400 \mathrm{~cm}^{-1}$ interval with a resolution of $4 \mathrm{~cm}^{-1}$, collected by adding 124 scans. SEM images were collected on an SEM system (LEO VP-35 FEM).

Preparation of Lanthanide-HPA Materials. Synthesis of Lanthanide-Containing Alginate Gels. For the syntheses in gels, the following stock solutions were prepared. By using the concentrated $\mathrm{H}_{3} \mathrm{HPA}$ starting solution, a more-dilute $0.133 \mathrm{M}$ stock solution was made. Fifteen milliliters $(15 \mathrm{~mL})$ of this solution contains $0.3 \mathrm{mmol}$ of $\mathrm{H}_{3} \mathrm{HPA}$. Using the solid lanthanide nitrates, $0.1 \mathrm{M}$ stock solutions were prepared in DI water. In a glass beaker, $1 \mathrm{~g}$ of sodium alginate was dissolved in $\sim 100 \mathrm{~mL}$ of DI water, thus generating a $1 \% \mathrm{w} / \mathrm{v}$ solution. Four milliliters $(4 \mathrm{~mL})$ of the above alginate stock solution are transferred into $25-\mathrm{mL}$ glass vials. Then, with a Pasteur pipet, $2 \mathrm{~mL}$ $(0.2 \mathrm{mmol})$ of the above lanthanide stock solutions were added. Upon addition of the lanthanide solution, immediate gel formation was observed. The forming gel was left undisturbed for at least $9 \mathrm{~h}$ to ensure maximum exchange of $\mathrm{Ln}^{3+}$ ions for $\mathrm{Na}^{+}$ions. Subsequently, the excess liquid was decanted, the gel was washed several times with DI water, and was then ready for the next step.

Gel-Assisted Preparation of Ln-HPA Materials. The method described below was applied for the following lanthanides: Ce, Pr, $\mathrm{Sm}, \mathrm{Gd}, \mathrm{Tb}$, and $\mathrm{Dy}$, The syntheses were performed in five different $\mathrm{pH}$ values: $0.2,0.4,0.6,0.8$, and 1.0. A volume of $15 \mathrm{~mL}$ of the abovedescribed $\mathrm{H}_{3} \mathrm{HPA}$ stock solution $\left(0.2 \mathrm{mmol}\right.$ in $\left.\mathrm{H}_{3} \mathrm{HPA}\right)$ was preacidified with $\mathrm{HCl}$ to the desired $\mathrm{pH}$ value and was then added to the beaker containing the Ln-containing alginate gel, using a Pasteur pipet. In this way, the gel is completely immersed in liquid. The vial containing the gel is covered and left undisturbed to stand for several days. Depending on the lanthanide used, crystals may form after 2 days, or longer. The formed crystals are left to grow until no further crystal growth can be detected by the naked eye. We have observed that, depending on the $\mathrm{Ln}: \mathrm{H}_{3} \mathrm{HPA}$ system, crystals may form on the surface of the gel, embedded inside the gel, or even at the bottom of the vial. After the crystallization reaction is complete, the gel is removed from the vial with a pair of small tongues and placed on filter paper on a vacuum filtration system. Usually, mechanical shaking in combination with washing with DI water is sufficient to completely dislodge the crystals from the gel. The isolated crystals are further washed with DI water and finally air-dried. All products are examined under an optical microscope to ensure that no contamination from the gel material is present. Common reaction yields range from $10 \%$ to $20 \%$.

Bulk Syntheses. For the bulk syntheses, preparation of $0.4 \mathrm{M}$ $\mathrm{H}_{3} \mathrm{HPA}$ and $0.4 \mathrm{M}$ Ln nitrate was necessary. Room-temperature reactions between the lanthanide of choice (see above) and $\mathrm{H}_{3} \mathrm{HPA}$ were carried out in conventional glassware. Four different $\mathrm{Ln}: \mathrm{H}_{3} \mathrm{HPA}$ molar ratios were tested: 1:1, 1:2, 1:3, and 1:5. Also, the final reaction volumes were varied $(20,40,60$, and $80 \mathrm{~mL})$. In a glass beaker containing the desired volume of DI water (see above), $0.5 \mathrm{~mL}(0.2$ $\mathrm{mmol}$ ) of the $0.4 \mathrm{M}$ Ln stock solution was placed. Then, the desired volume of the $0.4 \mathrm{M} \mathrm{H}_{3} \mathrm{HPA}$ stock solution was added. For example, if the desired $\mathrm{Ln}: \mathrm{H}_{3} \mathrm{HPA}$ molar ratio is $1: 1$, then $0.5 \mathrm{~mL}$ of the $\mathrm{Ln}$ stock solution is added. The $\mathrm{pH}$ value was adjusted to $\sim 1.0$ using $\mathrm{HCl}$. The beaker is then covered with parafilm, holes are punctured for slow water evaporation, and the reaction mixture is left undisturbed for 
several days. It is frequently monitored for crystal formation. When no further crystal growth is noted, the formed microcrystalline solids (almost invariably polycrystalline aggregates in spherical form) are isolated by filtration, washed with DI water, and air-dried. Three solid solutions- $\mathrm{Eu}_{0.95} \mathrm{~Tb}_{0.05} \mathrm{HPA}, \mathrm{Eu}_{0.9} \mathrm{~Tb}_{0.1} \mathrm{HPA}$ and $\mathrm{Gd}_{0.95} \mathrm{~Tb}_{0.05} \mathrm{HPA}-$ were prepared following the above-described procedure and using a $\mathrm{Ln}: \mathrm{H}_{3} \mathrm{HPA}$ overall molar ratio of 1:1. The final reaction volume was 40 $\mathrm{mL}$, and the solution $\mathrm{pH}$ was in the range of $0.80-1.50$ (depending on individual synthesis). Low $\mathrm{pH}$ values were chosen in order to avoid quick precipitation and allow the formation of crystalline products. Routinely, yields of $\sim 50 \%$ are noted, based on the metal. FT-IR spectra of all materials are essentially identical. As an example, the main bands in the FT-IR spectrum $\left(\mathrm{cm}^{-1}\right)$ of Ln-HPA are as follows: 3345 (br), 3203 (br), 2652 (w), 2626 (sh), 1577 (s), 1423 (m), 1371 (sh), 1273 (w), 1165 (sh), 1160 (s), 979 (m), 821 (w). Some representative syntheses were also tried under hydrothermal conditions $\left(\mathrm{Ln}=\mathrm{La}, \mathrm{Ce}, 120^{\circ} \mathrm{C}, \mathrm{pH} 1.0,1.5,2.0\right)$ and the resulting products were the same as those from the $\mathrm{RT}$ syntheses.

Anal. Calcd for $\mathrm{La}_{3}\left(\mathrm{H}_{075} \mathrm{O}_{3} \mathrm{PCHOHCOO}\right)_{4} \cdot 16 \mathrm{H}_{2} \mathrm{O}: 7.27 \% \mathrm{C}, 3.28 \%$ H. Found: $7.33 \% \mathrm{C}, 3.57 \% \mathrm{H}$. Calcd weight loss $\left(900{ }^{\circ} \mathrm{C}\right): 43.0 \%$; Found: $43.9 \%$. Anal. Calcd for $\mathrm{Ce}_{3}\left(\mathrm{H}_{0.75} \mathrm{O}_{3} \mathrm{PCHOHCOO}\right)_{4} \cdot 16 \mathrm{H}_{2} \mathrm{O}$ : $7.26 \%$ C, $3.27 \%$ H. Found: $7.41 \%$ C, 3.39\% H. Calcd weight loss $(900$ $\left.{ }^{\circ} \mathrm{C}\right): 41.4 \%$; Found: $43.0 \%$. Anal. Calcd for $\mathrm{Pr}_{3}\left(\mathrm{H}_{0.75} \mathrm{O}_{3} \mathrm{PCHOHCOO}\right)_{4} \cdot 16 \mathrm{H}_{2} \mathrm{O}: 7.34 \%$ C, $3.16 \% \mathrm{H}$. Found: $7.27 \% \mathrm{C}, 3.04 \% \mathrm{H}$. Calcd weight loss $\left(900{ }^{\circ} \mathrm{C}\right): 41.3 \%$; Found: 43.9\%. Anal. Calcd for $\mathrm{Sm}_{3}\left(\mathrm{H}_{0.75} \mathrm{O}_{3} \mathrm{PCHOHCOO}\right)_{4} \cdot 16 \mathrm{H}_{2} \mathrm{O}: 7.07 \% \mathrm{C}$, $3.19 \% \mathrm{H}$. Found: $6.61 \% \mathrm{C}, 3.06 \% \mathrm{H}$. Calcd weight loss $\left(900{ }^{\circ} \mathrm{C}\right)$ : $42.7 \%$; Found: $42.8 \%$. Anal. Calcd for $\mathrm{Eu}_{3}\left(\mathrm{H}_{0.75} \mathrm{O}_{3} \mathrm{PCHOHCOO}\right)_{4} \cdot 16 \mathrm{H}_{2} \mathrm{O}: 7.05 \% \mathrm{C}$, $3.18 \% \mathrm{H}$. Found: $6.34 \% \mathrm{C}, 2.27 \% \mathrm{H}$. Calcd weight loss $\left(900{ }^{\circ} \mathrm{C}\right): 40.2 \%$; Found: 40.5\%. Anal. Calcd for $\mathrm{Gd}_{3}\left(\mathrm{H}_{0.75} \mathrm{O}_{3} \mathrm{PCHOHCOO}\right)_{4} \cdot 16 \mathrm{H}_{2} \mathrm{O}: 6.97 \% \mathrm{C}$, $3.15 \% \mathrm{H}$. Found: $6.47 \% \mathrm{C}, 3.01 \% \mathrm{H}$. Calcd weight loss $\left(900{ }^{\circ} \mathrm{C}\right)$ : $39.3 \%$; Found: $41.4 \%$. Anal. Calcd (\%) for $\mathrm{Tb}_{3}\left(\mathrm{H}_{0.75} \mathrm{O}_{3} \mathrm{PCHOHCOO}\right)_{4} \cdot 15 \mathrm{H}_{2} \mathrm{O}: 7.05 \% \mathrm{C}, 3.03 \% \mathrm{H}$. Found: $6.52 \% \mathrm{C}, 3.02 \% \mathrm{H}$. Calcd weight loss $\left(900{ }^{\circ} \mathrm{C}\right): 38.9 \%$; Found: $38.4 \%$. Anal. Calcd for $\mathrm{Dy}_{3}\left(\mathrm{H}_{0.75} \mathrm{O}_{3} \mathrm{PCHOHCOO}\right)_{4} \cdot 15 \mathrm{H}_{2} \mathrm{O}: 6.97 \% \mathrm{C}$, $3.00 \% \mathrm{H}$. Found: $6.28 \% \mathrm{C}, 2.82 \% \mathrm{H}$. Calcd weight loss $\left(900{ }^{\circ} \mathrm{C}\right)$ : 38.4\%; Found: $36.6 \%$.

Thermal Analysis. Differential thermal analysis (DTA) and thermogravimetric analysis (TGA) data were recorded on an SDTQ600 analyzer from TA Instruments. Initially, the temperature was varied from RT to $900{ }^{\circ} \mathrm{C}$ at a heating rate of $10{ }^{\circ} \mathrm{C} \min ^{-1}$. Measurements were carried out on a sample in an open platinum crucible under a flow of air. A second set of measurements were carried out under $\mathrm{N}_{2}$ flow, saturated with water at $25{ }^{\circ} \mathrm{C}$, to characterize the release and uptake of water by $\mathrm{La}_{3}\left(\mathrm{H}_{0.75} \mathrm{O}_{3} \mathrm{PCHOHCOO}\right)_{4} \cdot 16 \mathrm{H}_{2} \mathrm{O}$ (body-centered structure, see below (LaHPA-I)) and $\mathrm{Gd}_{3}\left(\mathrm{H}_{0.75} \mathrm{O}_{3} \mathrm{PCHOHCOO}\right)_{4} \cdot 16 \mathrm{H}_{2} \mathrm{O}$ (primitive structure; see below (GdHPA-II)).

Thermodiffractometric studies were carried out for both polymorphic phases of LaHPA with the sample loaded in an Anton Paar HTK $1200 \mathrm{~N}$ chamber under static air. Data were collected at 30, 40, 60,80 , and $90{ }^{\circ} \mathrm{C}$ with a heating rate of $5{ }^{\circ} \mathrm{C} \mathrm{min}{ }^{-1}$ and a delay time of $10 \mathrm{~min}$ to ensure thermal stabilization. The data acquisition range was $4^{\circ}-60^{\circ}(2 \theta)$ with a step size of $0.017^{\circ}$ and an equivalent counting time of $118 \mathrm{~s} / \mathrm{step}$. A second study for both polymorphs was carried out with the same camera, at room temperature, but under vacuum (final pressure $\sim 2.5 \times 10^{-4} \mathrm{bar}$ ) and at different times (from $1 \mathrm{~h}$ to 4 h). The data range was $4^{\circ}-50^{\circ}(2 \theta)$, with a step size of $0.033^{\circ}$ and an equivalent counting time of $50 \mathrm{~s} / \mathrm{step}$.

Solid-State NMR. ${ }^{31} \mathrm{P}$ and ${ }^{1} \mathrm{H}$ MAS (magic angle spinning) NMR spectra were recorded at 161.98 and $400.13 \mathrm{MHz}$, respectively, on a Bruker Avance 400 spectrometer. The external magnetic field was 9.4 T. All measurements were carried out at $20^{\circ} \mathrm{C}$ and the samples were spun around the magic angle $\left(54^{\circ} 44^{\prime}\right.$ with respect to the magnetic field) at spinning rates between $10 \mathrm{kHz}$ and $12 \mathrm{kHz}$. The ${ }^{31} \mathrm{P}$ MAS NMR spectra were obtained with two experimental sequences (single pulse and proton decoupling) after a $\pi / 2$ excitations of $4 \mu \mathrm{s}$, and intervals between successive accumulations of $30 \mathrm{~s} .{ }^{1} \mathrm{H}$ MAS NMR spectra were obtained with a single pulse sequence of $6-\mu$ s duration and $5 \mathrm{~s}$ of recycle delay. The ${ }^{31} \mathrm{P}$ chemical shift values are given relative to a $85 \% \mathrm{H}_{3} \mathrm{PO}_{4}$ aqueous solutions and those of ${ }^{1} \mathrm{H}$ relative to $\left(\mathrm{CH}_{3}\right)_{4} \mathrm{Si}$. The deconvolution of ${ }^{31} \mathrm{P}$ MAS NMR spectra was carried out using the DMFIT program, ${ }^{20}$ so that the different components and their contributions could be revealed.

Structure Determination and Refinement. Laboratory powder $\mathrm{X}$-ray diffraction (PXRD) patterns were collected on a PANanalytical X'Pert Pro diffractometer in a Bragg-Brentano reflection configuration by using a $\mathrm{Ge}(111)$ primary monochromator $\left(\mathrm{Cu} \mathrm{K} \alpha_{1}\right)$ and the X'Celerator detector. PXRD patterns were autoindexed using the DICVOL06 program, ${ }^{21}$ and the space groups were derived from the observed systematic extinctions. To minimize the preferred orientation effects, samples of CeHPA and PrHPA were mixed with a small amount ( $5 \%-10 \%$ in weight) of Cab-o-Sil M-5 (from Fluka), as previously reported. ${ }^{22}$ The PXRD patterns were recorded between $4^{\circ}$ and $100^{\circ}(2 \theta)$, with a $0.017^{\circ}$ step size and an equivalent counting time of $\sim 400 \mathrm{~s} /$ step.

All compounds crystallize as polycrystalline solids and only for CeHPA-I and GdHPA-II small single crystals (microcrystals) were isolated. Data for GdHPA-II were collected on an Agilent Technologies SuperNova Dual diffractometer equipped with an EOS $\mathrm{CCD}$ detector at $-173(2){ }^{\circ} \mathrm{C}$ with $\mathrm{Mo} \mathrm{K} \alpha(\lambda=0.71073 \AA)$, making omega scans when collecting the data, with a $1.0^{\circ}$ scan width and $80 \mathrm{~s}$ per frame exposure time. Cell refinement and data reduction were performed with CrysAlisPro. ${ }^{23}$ The structure was solved by direct methods ${ }^{24}$ revealing the positions of all non-hydrogen atoms. These atoms were refined on $F^{2}$ via a full-matrix least-squares procedure, ${ }^{24}$ using anisotropic displacement parameters. The $\mathrm{H}$-atoms were placed in calculated positions and refined using a riding model. Corrections for absorption were performed using the multiscan facilities implemented in CrysAlisPro. ${ }^{23}$ The contribution of the disordered solvent molecules to the overall intensity data of all structures were eliminated using the SQUEEZE method in PLATON. ${ }^{25}$

A CeHPA-I microcrystal was prepared for measurement under inert conditions immersed in perfluoropolyether protecting oil. It was mounted on a MiTeGen Micromount and then used for data collection. Data were collected $\left(\lambda=0.73780,-173{ }^{\circ} \mathrm{C}\right)$ at the ESRF synchrotron BM16 beamline (Grenoble, France). The data were processed with APEX2 and corrected for absorption using SADABS. ${ }^{26}$ The structure was solved by direct methods, ${ }^{27}$ revealing the position of all non-hydrogen atoms, except those corresponding to some water molecules. The localized atoms were refined on $F^{2}$ by a full-matrix least-squares procedure, using anisotropic displacement parameters; ${ }^{28}$ however, the refinement did not converge due to poor quality of the single microcrystals and the structural disorder. Thus, the obtained partial structure was used as initial model for a Rietveld refinement using laboratory PXRD. The used $2 \theta$ range for all refinements was $14^{\circ}-100^{\circ}(2 \theta)$, to avoid the strong effects of asymmetry and preferred orientation at very low angles.

The missing atoms were localized by difference of Fourier maps. The structures were refined by the Rietveld method, ${ }^{29}$ using the program GSAS ${ }^{30}$ and the graphic interface EXPGUI. ${ }^{31}$ To maintain chemically reasonable geometries for the carbon chain, as well as phosphonate and carboxylate groups, the following soft constraints were established: /PO3C1 tetrahedron $/ \mathrm{P}-\mathrm{O}[1.53(1) \AA], \mathrm{P}-\mathrm{C} 1$ $[1.80(1) \AA]$, O $\cdots \mathrm{O}[2.55(2) \AA], \mathrm{O} \cdots \mathrm{C} 1[2.73(2) \AA], / \mathrm{C} 1 \mathrm{OH}-\mathrm{C} 2 \mathrm{OO}$ group/C1-C2 [1.50(1) $\AA], \mathrm{C} 2-\mathrm{Ocarb}[1.23(1) \AA], \mathrm{C} 1-\mathrm{OH}[1.40(1)$ $\AA], \mathrm{P} \cdots \mathrm{OH}[2.68(2) \AA], \mathrm{C} 2-\mathrm{OH}[2.40(2) \AA], \mathrm{O}_{\text {carb }} \cdots \mathrm{O}_{\text {carb }}[2.21(2)$ $\AA]$, and $\mathrm{C} 1 \cdots \mathrm{O}_{\text {carb }}[2.36(2) \AA]$. Those $\mathrm{Ln}^{\mathrm{III}}-\mathrm{O}$ bond distances deviating by more than the $15 \%$ from the reported Shannon average values $^{32}$ were also constrained $[2.60(5) \AA]$ during the refinement. Water molecules for CeHPA-I and TbHPA-II were located in difference Fourier maps and included in the refinements. No attempts to locate the $\mathrm{H}$ atoms were carried out due to the limited quality of the PXRD data. The final weight factor for the constraints was 10. The atomic displacement parameters were fixed $\left(U_{\text {iso }}=0.01 \AA^{3}\right)$ and not refined for the LaHPA derivatives. For CeHPA-I, only a commom atomic displacement parameter was refined for all atoms. For TbHPAII, three atomic displacement parameters were isotropically refined, one for Ln atoms, another for both phosphorus atoms, and a third 
Table 1. Crystallographic Data for Lanthanide Hydroxyphosphonoacetate Hybrid Materials

\begin{tabular}{|c|c|c|c|c|}
\hline compound reference & LaHPA-I & LaHPA-II & CeHPA-I & GdHPA-II \\
\hline chemical formula & $\mathrm{C}_{8} \mathrm{O}_{40} \mathrm{H}_{43} \mathrm{P}_{4} \mathrm{La}_{3}$ & $\mathrm{C}_{8} \mathrm{O}_{40} \mathrm{H}_{43} \mathrm{P}_{4} \mathrm{La}_{3}$ & $\mathrm{C}_{8} \mathrm{O}_{401} \mathrm{H}_{43} \mathrm{P}_{4} \mathrm{Ce}_{3}$ & $\mathrm{C}_{8} \mathrm{O}_{40} \mathrm{H}_{43} \mathrm{P}_{4} \mathrm{Gd}_{3}$ \\
\hline formula mass & 1319.66 & 1319.74 & 1323.3 & 1376.80 \\
\hline crystal system & orthorhombic & orthorhombic & orthorhombic & orthorhombic \\
\hline$a$ & $13.4677(4) \AA$ & 13.3604(3) A & $13.4033(5) \AA$ & 13.0433(2) A \\
\hline$b$ & $26.8557(5) \AA$ & $26.2820(8) \AA$ & $26.6912(10) \AA$ & $25.7014(3) \AA$ \\
\hline$c$ & $11.1160(5) \AA$ & $11.2668(3) \AA$ & $11.0963(5) \AA$ & $11.07570(10) \AA$ \\
\hline$\alpha$ & $90.0^{\circ}$ & $90.0^{\circ}$ & $90.0^{\circ}$ & $90.0^{\circ}$ \\
\hline$\beta$ & $90.0^{\circ}$ & $90.0^{\circ}$ & $90.0^{\circ}$ & $90.0^{\circ}$ \\
\hline$\gamma$ & $90.0^{\circ}$ & $90.0^{\circ}$ & $90.0^{\circ}$ & $90.0^{\circ}$ \\
\hline unit-cell volume & $4020.5(3) \AA^{3}$ & $3956.2(2) \AA^{3}$ & $3969.69(34) \AA^{3}$ & $3712.92(8) \AA^{3}$ \\
\hline temperature & $20^{\circ} \mathrm{C}$ & $20^{\circ} \mathrm{C}$ & $20^{\circ} \mathrm{C}$ & $-173(2){ }^{\circ} \mathrm{C}$ \\
\hline space group & $I b a 2$ & Pcan & $I b a 2$ & Pcan \\
\hline Z & 4 & 4 & 4 & 4 \\
\hline$R_{\text {int }}$ & & & & 0.0315 \\
\hline No. independent reflections & 1102 & 1102 & 868 & 3274 \\
\hline data (reflections)/ restrains/parameters & $5121 / 62 / 128$ & $5273 / 38 / 115$ & $4705 / 55 / 120$ & $16585 / 0 / 213$ \\
\hline$R$ factor $[\mathrm{I}>2 \sigma(\mathrm{I})]$ & & & & ${ }^{a} \mathrm{R} 1=0.0233{ }^{a}{ }^{\mathrm{w} R} 2=0.0608$ \\
\hline$R$ factor (all data) & & & & ${ }^{a} \mathrm{R} 1=0.0253 ;{ }^{a} \mathrm{wR} 2=0.0617$ \\
\hline$R_{\mathrm{WP}} / R_{\mathrm{WP}^{\prime}} b$ & $0.086 / 0.104$ & $0.055 / 0.059$ & $0.044 / 0.050$ & \\
\hline$R_{\mathrm{P}}$ & 0.063 & 0.043 & 0.034 & \\
\hline$R_{\mathrm{F}} / \mathrm{GoF}$ & $0.0642 /-$ & $0.0323 /-$ & $0.0354 /-$ & $-/ 1.071$ \\
\hline CCDC number & 846353 & 872882 & 846355 & 871628 \\
\hline
\end{tabular}

${ }^{a} R 1(F)=\sum\left\|F_{\mathrm{o}}|-| F_{\mathrm{c}}\right\| / \sum\left|F_{\mathrm{o}}\right| ; w R 2\left(F^{2}\right)=\left[\sum w\left(F_{\mathrm{o}}{ }^{2}-F_{\mathrm{c}}{ }^{2}\right)^{2} / \sum F^{4}\right]^{1 / 2} \cdot{ }^{b} R_{\mathrm{WP}} / R_{\mathrm{WP}^{\prime}}$ represents the Rietveld disagreement weighted profile factors with and without background contribution, respectively.

value for the remaining atoms. Rietveld plots for LaHPA-I, LaHPA-II, CeHPA-I, and TbHPA-II are given in the Figures S1-S4 in the Supporting Information (SI). The final structural model obtained for CeHPA-I (from the PXRD data) and GdHPA-II (from single-crystal data) were used as starting model for the structural refinement of the remaining members of the both series. Crystallographic data for LaHPA-I, LaHPA-II, CeHPA-I, and GdHPA-II are presented in Table 1 , along with their corresponding CCDC reference codes. The crystallographic data for the remaining LnHPA compounds are given in Table S1 in the SI.

Textural Characterization. The nitrogen sorption-desorption isotherms were measured in a Micromeritic ASAP 2020 apparatus. The samples were degassed under high vacuum and the isotherms, obtained at $-196^{\circ} \mathrm{C}$, were analyzed by the Brunauer-Emmett-Teller (BET) method. Carbon dioxide sorption isotherms were measured in a Micromeritic ASAP 2020 apparatus. The samples were degassed at room temperature for several hours and the isotherms obtained at 0 ${ }^{\circ} \mathrm{C}$ were analyzed by the Dubinin-Radushkevich (DR) method. ${ }^{33}$

Proton Conductivity Studies. Electrical characterization for LaHPA-I and GdHPA-II was carried out on cylindrical pellets (diameter of $\sim 10 \mathrm{~mm}$ and thickness of $\sim 1 \mathrm{~mm}$ ) obtained by pressing $\sim 0.2 \mathrm{~g}$ of sample at $1000 \mathrm{MPa}$, for $2 \mathrm{~min}$. The pellets were pressed between porous $\mathrm{C}$ electrodes (Sigracet, GDL $10 \mathrm{BB}$, no Pt). Impedance spectroscopy data were collected using a HP4284A impedance analyzer over the frequency range from $20 \mathrm{~Hz}$ to $1 \mathrm{MHz}$ with an applied voltage of $0.2 \mathrm{~V}$. Electrical measurements were taken from 21 to $11{ }^{\circ} \mathrm{C}$ in $2{ }^{\circ} \mathrm{C}$ steps under variable relative humidities (\% $\mathrm{RH}$ ), which were obtained by a continuous flow of water-saturated air through the cell. The air was bubbled in a thermostatic Julabo F32 water bath at different temperatures, with a precision of $0.1{ }^{\circ} \mathrm{C}$. The pellet was equilibrated at a given $\mathrm{RH}$ for $90 \mathrm{~min}$ to ensure a fixed water content of the sample. A small temperature range, $10{ }^{\circ} \mathrm{C}$, has been selected in order to have fixed water content for the studied samples and to have an approximately constant $\mathrm{RH}$. All measurements were electronically controlled by the winDETA package of programs. ${ }^{34}$

Photoluminescence Measurements. Steady-state photoluminescence measurements were recorded in a Photon Technology International (PTI) 220B spectrofluorimeter having a Xe arc lamp light excitation and Czerny-Turner monochromator, coupled to a photomultiplier. Time-resolved measurements were performed using a PTI spectrofluorimeter with a $\mathrm{Xe}-\mathrm{Hg}$ flash lamp ( $2 \mu$ s/pulse half $)$ as excitation pulse and a Czerny-Turner monochromator. The solid samples were pressed between two windows Suprasil quartz cuvettes with a path length of $0.01 \mathrm{~mm}$ and placed at a $45^{\circ}$ angle to both the excitation and emission monochromators. All measurements were carried out at room temperature.

\section{RESULTS AND DISCUSSION}

Syntheses. Initial synthetic attempts were focused on the crystal growth of LnHPA products in alginate gels. This methodology has been successful for a variety of metal phosphonate compounds. ${ }^{35}$ This approach takes advantage of initial lanthanide coordination by the carboxylate groups within the alginate hydrogel. ${ }^{36}$ Subsequently, the added $\mathrm{H}_{3} \mathrm{HPA}$ ligand coordinates to the Ln center, thus creating the initial nuclei that grow within days.

In room-temperature syntheses, many factors can be easily controlled, such as $\mathrm{pH}$ and Ln:HPA ratio. The former was varied from 0.80 to 1.50 and the latter from $1: 1$ to $1: 5$ with similar results. The effect of $\mathrm{pH}$ on the morphology of the end materials was studied by electron microscopy, and the results are shown in Figure 1. It appears that the lower the synthesis $\mathrm{pH}$, the larger the platelike crystals that form the aggregates. Macroscopically, the aggregates take a semispherical shape. However, upon closer examination (see, for example, the CeHPA case at $\mathrm{pH} 0.84$ ), the aggregates are composed of smaller, platelike crystals.

Structural Study. All reported compounds, $\mathrm{Ln}_{3}\left(\mathrm{H}_{0.75} \mathrm{O}_{3} \mathrm{PCHOHCOO}\right)_{4} \cdot x \mathrm{H}_{2} \mathrm{O}(\mathrm{Ln}=\mathrm{La}, \mathrm{Ce}, \mathrm{Sm}, \mathrm{Pr}, \mathrm{Gd}$, $\mathrm{Eu}, \mathrm{Tb}, \mathrm{Dy} ; x=15-16)$ crystallize in the orthorhombic system. Two types of structures were isolated, hereafter identified as series I and II polymorphs. Series I compounds crystallize in a noncentrosymmetric structure (e.g. I $b a 2$ ), whereas series II samples crystallize in a centrosymmetric structure (e.g., Pcan). In addition to the structural analysis, the change in the crystal 


\begin{tabular}{|c|c|c|c|c|}
\hline $\begin{array}{c}\text { Lanthanide-HPA } \\
\text { Framework }\end{array}$ & Series & Synthesis pH & $\begin{array}{c}\text { Crystal } \\
\text { Morphology }\end{array}$ & $\begin{array}{l}\text { Aggregate } \\
\text { Size }\end{array}$ \\
\hline La & II & 1.50 & & $\sim 600 \mu \mathrm{m}$ \\
\hline $\mathrm{Ce}$ & 1 & 0.86 & & $\sim 400 \mu \mathrm{m}$ \\
\hline $\mathrm{Ce}$ & $\begin{array}{l}\text { mixture } \\
\text { I and II }\end{array}$ & 1.34 & & $\sim 600 \mu \mathrm{m}$ \\
\hline $\mathrm{Ce}$ & $\begin{array}{l}\text { mixture } \\
I \text { and } \|\end{array}$ & 1.40 & & $\sim 500 \mu \mathrm{m}$ \\
\hline $\mathrm{Ce}$ & II & 1.52 & & $\sim 300 \mu \mathrm{m}$ \\
\hline Pr & $\begin{array}{l}\text { mixture } \\
\text { I and II }\end{array}$ & 1.30 & & $\sim 200 \mu \mathrm{m}$ \\
\hline Sm & II & 0.78 & & $\sim 100 \mu \mathrm{m}$ \\
\hline Gd & II & 0.94 & & $\sim 400 \mu \mathrm{m}$ \\
\hline $\mathrm{Tb}$ & II & 1.24 & & $\sim 300 \mu \mathrm{m}$ \\
\hline Dy & II & 1.33 & & $\sim 300 \mu \mathrm{m}$ \\
\hline
\end{tabular}

Figure 1. Crystal morphologies of the Ln-HPA products.

symmetry is qualitatively evidenced upon comparing the XRD patterns (see Figure 2), by the presence of a several small

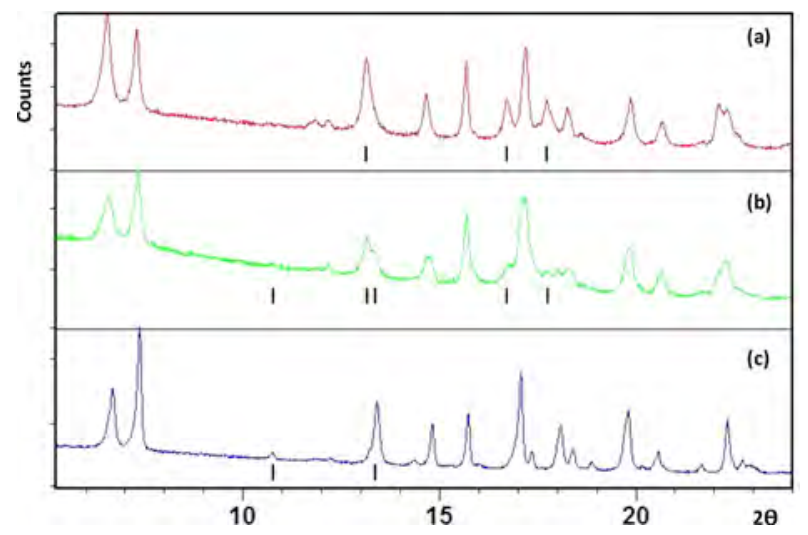

Figure 2. X-ray diffraction (XRD) patterns, with some representative reflections highlighted, corresponding to (a) LaHPA-I ( $\mathrm{pH}$ 0.8, e.g., Iba2), (b) mixture of the two polymorphs ( $\mathrm{pH} 0.9$ ), and (c) LaHPA-II ( $\mathrm{pH}$ 1.1, e.g. Pcan).

intensity peaks corresponding to reflections forbidden in the body-centered cell. It must be emphasized that, for the lanthanum derivative, the polymorphic phase LaHPA-I was obtained for $\mathrm{pH}$ values lower than 0.8, whereas LaHPA-II was prepared at $\mathrm{pH}$ values higher than 1.0. Syntheses at intermediate $\mathrm{pH}$ values led to a mixture of phases (see Figure 2).

The unit-cell volumes range between 4020.3(3) $\AA^{3}$ (LaHPAI) and 3698.4(4) $\AA^{3}$ (DyHPA-II) (see Table S1 in the SI). Data reported in Table $S 1$ in the SI indicate that the $b$-axis, defining the direction of the layer packing, shrinks slightly more than the $a$ - and $c$-axes. Figure 3 shows that, for both series, the cell volume decreases linearly with the ionic radius (average $\mathrm{CN}=$

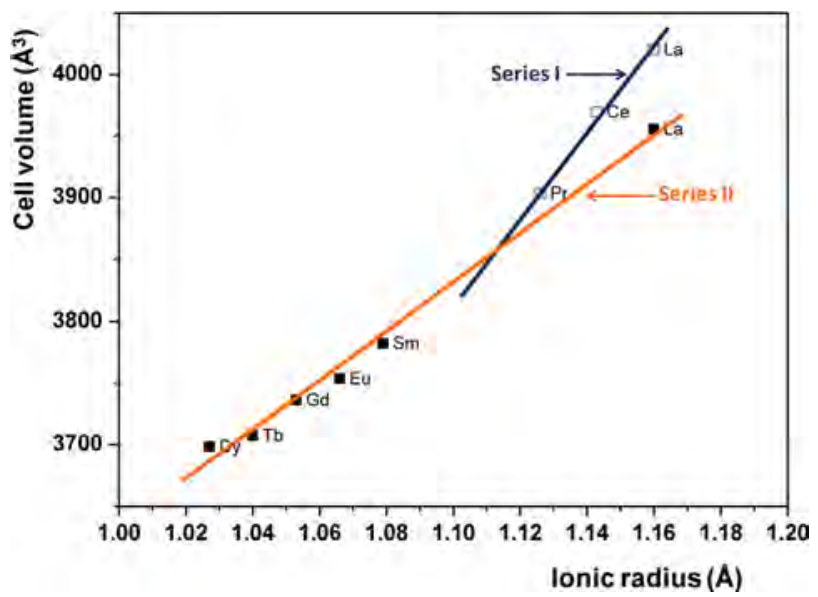

Figure 3. Variation of unit-cell volumes with the lanthanide ionic radius for the two LnHPA series.

8) but with different slopes. As discussed below, these two series contains different trimeric units, which justifies the slightly different slopes. According to Figure 3, series I ( $\mathrm{Ln}=$ $\mathrm{La}, \mathrm{Ce}$, and $\mathrm{Pr}$ ) materials would have unit-cell volumes bigger than those of series II. The intersection point, $r \approx 1.11 \AA$, would correspond to $\mathrm{Nd}^{3+}$. However, heavier lanthanides hybrids, those with $r<1.11 \AA$, crystallize only in series II type structures, under the investigated experimental conditions.

Suitable single (micro)crystals of CeHPA-I and GdHPA-II were obtained. However, only the crystal structure of GdHPAII could be successfully refined. The content of the asymmetric unit for GdHPA-II is given in Figure 4. This part contains two

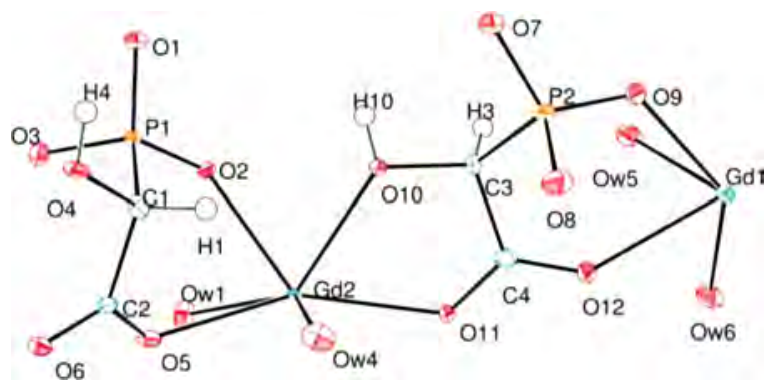

Figure 4. Asymmetric unit for GdHPA-II with the atoms labeled and the thermal ellipsoids shown at the $50 \%$ probability level.

lanthanide atoms (one in special position (Gd1) and a second one in a general position $(\mathrm{Gd} 2)$ ), two $\mathrm{H}_{x} \mathrm{HPA}$ ligands (P1 and $\mathrm{P} 2$ ), and four Gd-bound water molecules. In addition, the unit cell contains four disordered water molecules, as determined in the chemical analysis that was modeled with the SQUEEZE program in PLATON and treated as an unlocalized contribution to the overall scattering. It must be underlined that the layer connectivity observed for series II, represented by GdHPA-II, is maintained in series I, represented by CeHPA-I (see below), which results in similar frameworks, despite their different crystal symmetries.

The structures of these compounds can be described as being composed of organic-inorganic layers in the ac-plane connected by lanthanide cations along the $b$-axis. Remarkably, the layer atomic arrangement in the ac-plane is the same in both series (see Figure S5 in the SI), despite the different crystal symmetries. These layers contain infinite chains, running 
along the $a$-axis, formed by two types of chelating rings. These rings are 6-membered, $\mathrm{Ln} 2-\mathrm{O}-\mathrm{C}-\mathrm{C}-\mathrm{P} 1-\mathrm{O}-\mathrm{Ln} 2$ and 5membered, $\mathrm{Ln} 2-\mathrm{O}-\mathrm{C}-\mathrm{C}-\mathrm{O}-\mathrm{Ln} 2$ (see Figure $\mathrm{S} 5$ in the $\mathrm{SI}$ ). These chains are linked together along the $c$-axis just by the $\mathrm{P} 1-\mathrm{O} 1-\mathrm{Ln} 2$ linkage developing the organic-inorganic layers. This layer-binding mode resembles that found in M(II)HPA compounds $^{37}$ and $\operatorname{Ln}(\mathrm{III})$-oxalatocarboxyphosphonates. ${ }^{38}$ Thus, the 3D framework may be envisaged as a layered structure formed by $\{\operatorname{Ln} 2(\mathrm{P} 1)\}^{+}$units (see Figure S5 in the SI), and pillared along the $b$-axis by $\operatorname{Ln} 1\{\mathrm{P} 2\}_{2}$ units, see Figure 5 , to give the open frameworks shown in Figure 6.

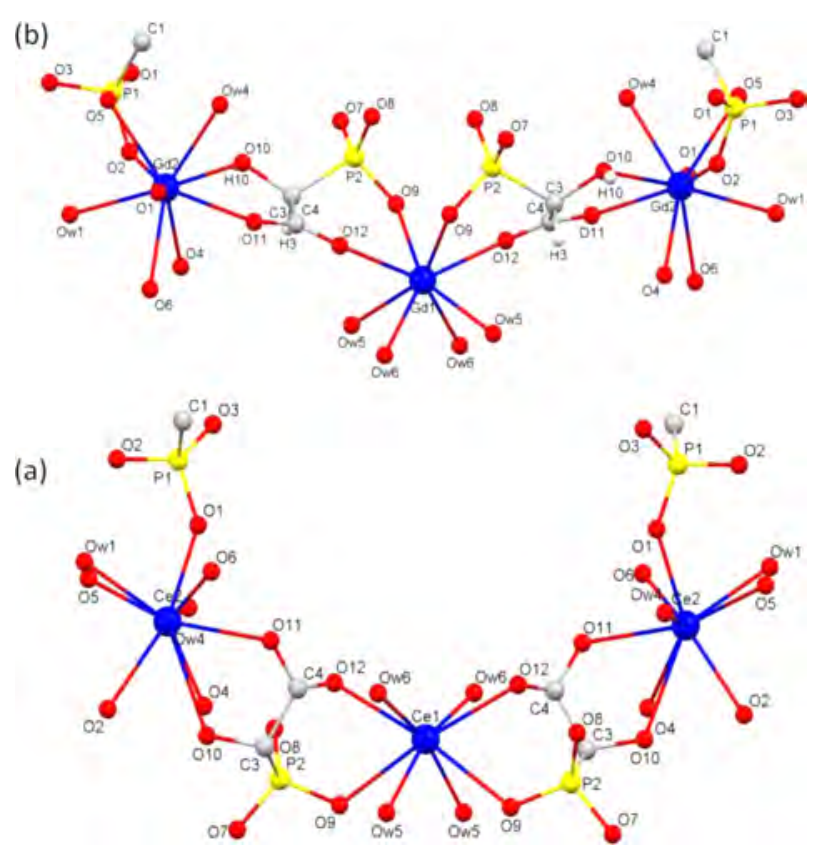

Figure 5. View of the trimeric units Ln2O9-Ln1O8-Ln2O9 for (a) series I and (b) series II, with atoms labeled, showing the different arrangement adopted by the carboxyphosphponate groups P2 and Ln1-bound water molecules (Ow5 and Ow6).

Figure 5 depicts the connectivity between the ac-layers for both series. For the GdHPA-II series, Ln1 is 8-coordinated with four sites being occupied by water molecules $[2 \times$ Ow5, $2 \times$ Ow6]. The remaining four positions are occupied by two pairs of oxygen atoms belonging to the phosphonate [O9] and carboxylate [O12] groups of two P2 ligands.

For CeHPA-I, the overall octa-coordination around $\operatorname{Ln}(1)$ is maintained. However, the different arrangement of the water molecules bound to interlayer-Ln1 in both series must be emphasized. Thus, for series II, the four waters of the Ln1 point outward in opposite directions, toward the phosphonate groups P2. Meanwhile, for series I, they are situated between the two P2 groups (see Figure 5). For both series, intralayer-Ln2 is 9coordinated. Seven coordination positions are provided by three P1 ligands and one P2 ligand. Two P1 ligands chelate Ln2 through pairs of oxygen atoms from either the phosphonate and the carboxylate groups [O2, O5] or the hydroxyl and carboxylate groups $[\mathrm{O} 4, \mathrm{O} 6]$. A third P1 ligand binds to Ln2 by only one oxygen atom from the phosphonate group, [O1] (see Figure S5 in the SI). Two more sites are occupied by a pair of oxygen atoms from the hydroxyl [O10] and the carboxylate [O11] groups of a P2 ligand than joins the layers along the $b$ axis. The coordination is completed by two water molecules
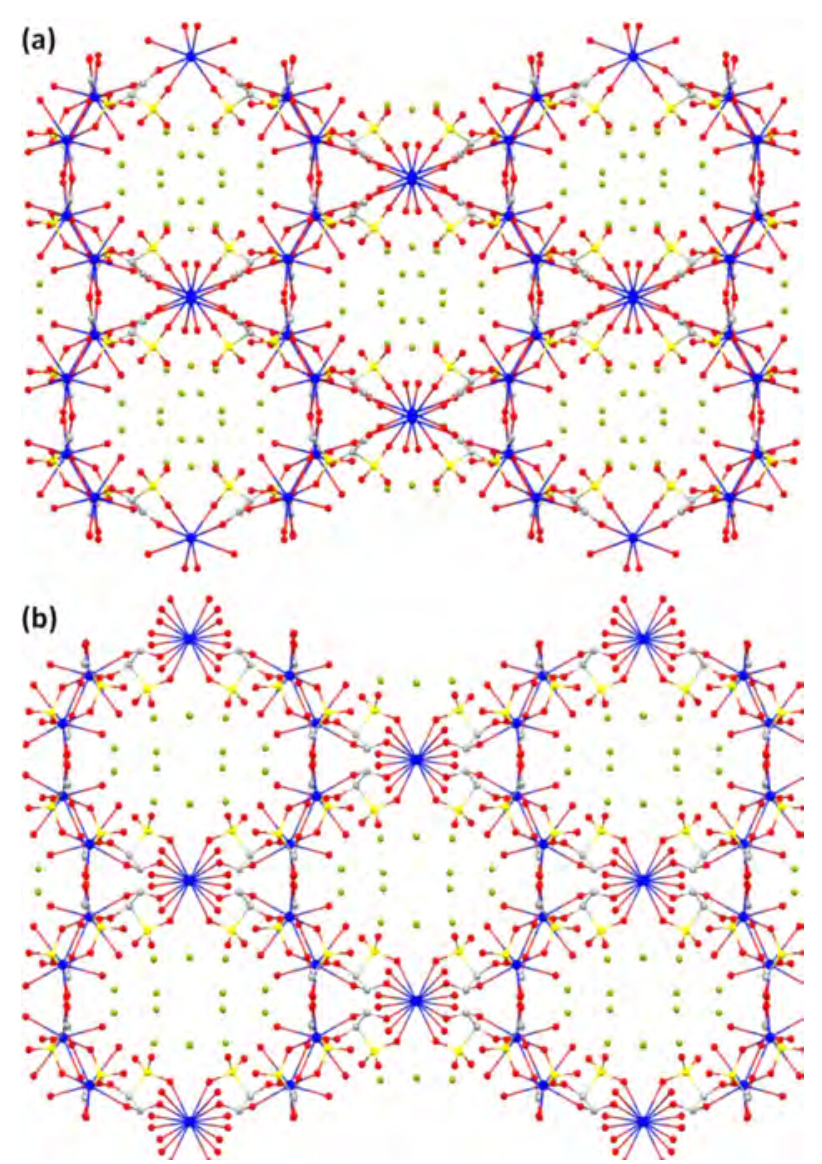

Figure 6. $c$-axis view ( $b$-axis horizontal) of the crystal structures for Ln hybrids showing the $1 \mathrm{D}$ channels along the $c$-axis filled with lattice waters for (a) LaHPA-II and (b) LaHPA-I. The lattice water molecules occupying the channels are highlighted in green.

Ow1 and Ow4. This arrangement results in $\mathrm{Ln}_{2} \mathrm{O}_{9}-{\mathrm{Ln} 1 \mathrm{O}_{8}-}^{-}$ $\mathrm{Ln}_{2} \mathrm{O}_{9}$ trimers (see Figure 5), which are similar to those found in $\mathrm{CaHPA}^{39}$ and $\mathrm{CdHPA}^{40}$ derivatives.

For both series, the 3D frameworks result from trimeric units interconnecting the layers. Large oval-shaped channels are formed by the spatial separation of the layers along the $b$-axis. The resulting open-framework structures enclose $1 \mathrm{D}$ channels running parallel to the $c$-axis, filled with lattice water molecules (see Figure 6b).

Some structural variations are found in the Ln series when compared to the CaHPA trimer found in $\mathrm{Ca}_{3}(\mathrm{HPA})_{2}\left(\mathrm{H}_{2} \mathrm{O}\right)_{14 \cdot}{ }^{15}$ For instance, the central Ln1 atom is 8-coordinated, whereas the central $\mathrm{Ca}$ atom in the CaHPA trimer is 6-coordinated. This higher coordination of $\operatorname{Ln} 1$ is likely the cause of a decrease in the $\operatorname{Ln} 2-\operatorname{Ln} 1-\operatorname{Ln} 2$ angle, with respect to that of $\mathrm{Ca} 2-\mathrm{Ca} 1-\mathrm{Ca} 2$, which was $180^{\circ}$. A more pronounced bending in the $\mathrm{Ln}-\mathrm{Ln}-\mathrm{Ln}$ angle is found for series I frameworks. Hence, the $\operatorname{Ln} 2-\operatorname{Ln} 1-\operatorname{Ln} 2$ angle varies from $142.7^{\circ}$ (series II) to $126.4^{\circ}$ (series I). These variations in $\mathrm{Ln}-\mathrm{Ln}-\mathrm{Ln}$ angles force the position of phosphonate group, P2, which connects $\operatorname{Ln} 1$ to $\operatorname{Ln} 2$. Hence, intratrimer P2 ‥P2 distance is 7.26(2) $\AA$ and 4.41(2) $\AA$ for series II and series I, respectively. On the other hand, and on the basis of the presence of a chiral carbon center in the HPA ligand, the central lanthanide ion in the trimeric SBU shows a preference for the $S$ isomer of $\mathrm{P} 2$, thus exerting chirality to the $\operatorname{Ln} 1\{\mathrm{P} 2\}_{2}$ unit. This trend is maintained along the series. These chiral 
units are encapsulated between layers formed from a $R$ and $S$ racemic mixture of ligands.

The water molecules occupying the $1 \mathrm{D}$ channels in the structure of GdHPA-II are found in a disordered arrangement and could not be positioned from single-crystal data. However, an attempt to localize the water molecules was carried out from powder diffraction data for TbHPA-II and CeHPA-I. The structural formula can be expanded as $\mathrm{Ln}_{3} \mathrm{H}\left(\mathrm{O}_{3} \mathrm{PCH}(\mathrm{OH})\right.$ $\mathrm{COO})_{2}\left(\mathrm{HO}_{3} \mathrm{PCH}(\mathrm{OH}) \mathrm{COO}\right)_{2}\left(\mathrm{H}_{2} \mathrm{O}\right)_{8} \cdot 8 \mathrm{H}_{2} \mathrm{O}$, in order to highlight (a) the disordered nature of one proton and (b) the two types of water molecules: one coordinated to the lanthanide and the second filling the center of the channels (i.e., lattice water). For the two series, four crystallographically independent lattice water oxygens could be found which are grouped in two "types": (i) two water molecules are located close to the wall of the channels, which are interacting strongly through hydrogen bonding with phosphonate and carboxylate groups; and (ii) two additional water molecules close to the center of the channels (see Figure $6 \mathrm{~b}$ ).

Information about possible structural rearrangements upon water removal was revealed by analyzing the XRD patterns of the samples subjected to dehydration-rehydration cycles under vacuum at room temperature (Figure 7). LaHPA-I progressively loses crystallinity, becoming amorphous after $4 \mathrm{~h}$ of treatment, with the final pressure reaching $\sim 2 \times 10^{-4}$ mbar. This sample did not recover its crystallinity when exposed to air or under a humid atmosphere of saturated $\mathrm{NaCl}$ for 7 days. However, after moistening the sample $(12 \mathrm{mg})$ with 3 drops of water and subsequent air-drying, the amorphous compound
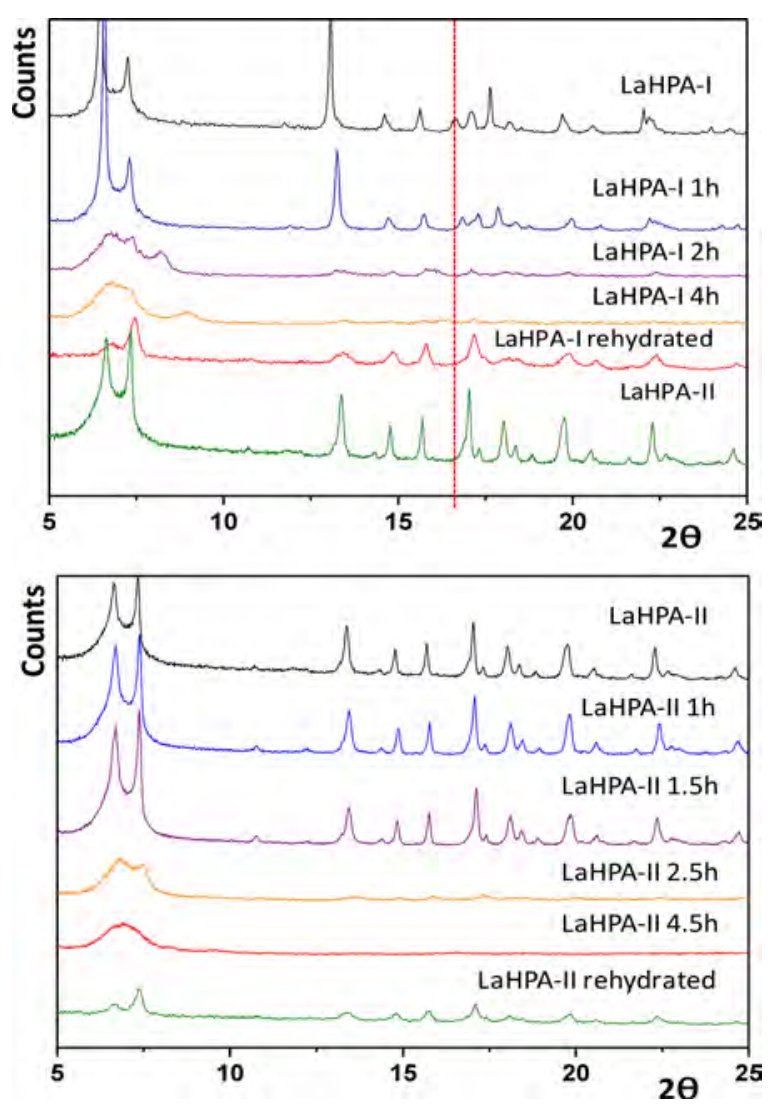

Figure 7. Structural evolution of both polymorphic forms, LaHPA-I and LaHPA-II, during the dehydration-rehydration processes under vacuum at room temperature. was converted to a crystalline material with series II crystal structure. Therefore, a complete cycle of water desorption under vacuum, followed by readsorption resulted in a change of symmetry from $I b a 2$ to Pcan. Under the same conditions, series II materials displayed amorphization upon dehydration but subsequent rehydration led to the same type of structure (see Figure 7). The necessity of a few drops of liquid water to ensure the rearrangement from phase I to phase II, via the amorphous phase, does not allow one to rule out recrystallization in the presence of liquid water.

Thermal Behavior and Surface Characterization. The two polymorphic phases I and II can be distinguished by their slightly different thermal behaviors. As an example, TG-DTA curves for LaHPA-I and LaHPA-II are shown in Figure 8. For

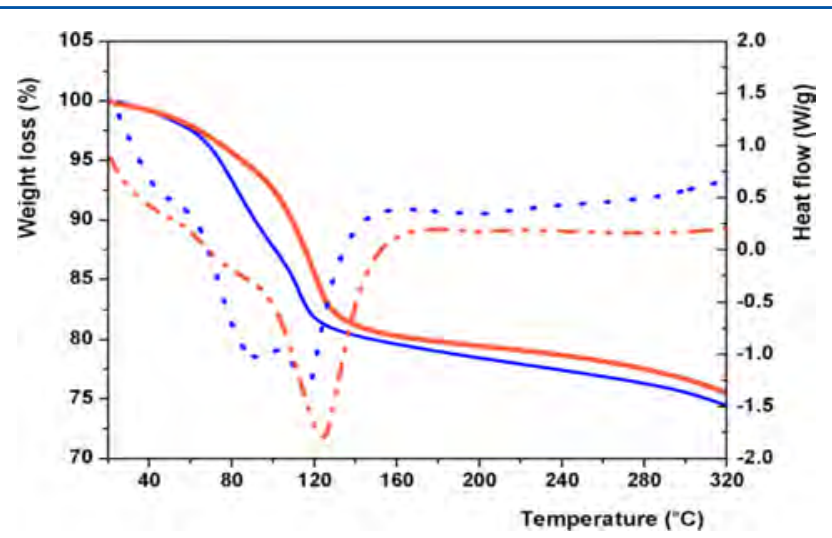

Figure 8. TGA (solid lines) and DTA (dots) curves for LaHPA-I (blue) and LaHPA-II (red) polymorphic forms of $\mathrm{La}_{3}\left(\mathrm{H}_{0.75} \mathrm{O}_{3} \mathrm{PCHOHCOO}\right)_{4} \cdot 16 \mathrm{H}_{2} \mathrm{O}$.

both series, dehydration starts at $35-40{ }^{\circ} \mathrm{C}$ and it is completed at $\sim 180{ }^{\circ} \mathrm{C}$, with most of the water content being removed below $140{ }^{\circ} \mathrm{C}$. The heat flow curve reveals three overlapping steps of dehydration. The overall weight loss is shifted to higher temperature for LaHPA-II, suggesting a stronger $\mathrm{H}$-bond interaction of water in this framework. This is consistent with the smaller unit cell volumes found for series II compounds. Similar dehydration patterns were observed for all compounds of each series.

For series I materials, lattice water is likely lost below $100{ }^{\circ} \mathrm{C}$, since the weight loss percentage (10.5 wt \%) closely matches the theoretical value for eight lattice water molecules $(10.91 \mathrm{wt}$ $\%$ ), while the metal-bound water is lost between $100{ }^{\circ} \mathrm{C}$ and $200{ }^{\circ} \mathrm{C}$. However, for series II materials, a clear separation between lattice and metal-bound water removal was indistinguishable. Unfortunately, no discernible plateau was detected between the loss of lattice water and the loss of water bound to the lanthanide cations. All attempts to prepare the materials as crystalline compounds without the lattice water (i.e., $\left.\mathrm{Ln}_{3}\left(\mathrm{H}_{0.75} \mathrm{O}_{3} \mathrm{PCHOHCOO}\right)_{4}\left(\mathrm{H}_{2} \mathrm{O}\right)_{8}\right)$ were unsuccessful. Above $240{ }^{\circ} \mathrm{C}$, thermal decomposition takes place. The total water content was also estimated from the weight loss up to $900{ }^{\circ} \mathrm{C}$, assuming the thermal decomposition product to be composed of amorphous $\mathrm{P}_{2} \mathrm{O}_{5}$, together with crystalline $\mathrm{LnPO}_{4}$ (Joint Committee on Powder Diffraction File (PDF) Card No. 01-084-0600). The calculated water content ranged from 15 to 16 water molecules per formula, which is consistent with the elemental analyses and the crystallographic study.

The dehydration processes for series I and II hybrids were also followed by thermodiffractometry under an open 
atmosphere (see Figures S6 and S7, respectively, in the SI). In agreement with the thermal analysis, series II compounds exhibit a slightly higher thermal stability. GdHPA-II heated at $120{ }^{\circ} \mathrm{C}$ yielded a crystalline pattern (see Figure S7 in the SI), with the amorphization starting at $130{ }^{\circ} \mathrm{C}$. A sample of GdHPA-II was first heated at $150{ }^{\circ} \mathrm{C}$ and was subsequently partially rehydrated after moistening with water and air-drying, but no phase transition ( $\mathrm{II} \rightarrow \mathrm{I})$ was observed. Amorphization for LaHPA-I starts close to $80{ }^{\circ} \mathrm{C}$ and the sample heated at 100 ${ }^{\circ} \mathrm{C}$ yielded a quasi-amorphous pattern (see Figure S6 in the SI); this temperature corresponds to the loss of half of the hydration waters, as monitored by thermal analysis. Again, the resulting rehydrated compound, following the procedure described above, has the typical pattern of series II compounds. This behavior suggests that series II, with smaller unit-cell volume, is the most stable polymorph for LnHPA hybrids.

The textural properties for LaHPA-I and LaHPA-II were studied by outgassing the samples under high vacuum at room temperature for several hours until a mass loss equivalent to the full removal of the lattice waters occurred. The $\mathrm{N}_{2}$ isotherms gave no porosity and only a low $\mathrm{CO}_{2}$ adsorption (isotherms not shown), with micropore surface areas of $\sim 85 \mathrm{~m}^{2} \mathrm{~g}^{-1}$, deduced from the Dubinin-Radushkevich equation. ${ }^{33}$

FT-IR Spectroscopy. Selected spectra for CeHPA-I, PrHPA-I, GdHPA-II, and TbHPA-II, are given in Figure S8 in the SI. A followup of sample LaHPA-I, heated in situ at selected temperatures up to $190{ }^{\circ} \mathrm{C}$, is also shown in Figure S9 in the SI. All LnHPA hybrids show similar FT-IR spectra and only small differences in the widths and intensities of the bands are observed. The broad $\mathrm{O}-\mathrm{H}$ stretching region confirms the existence of several types of water molecules interacting through H-bonds with variable strength, from weak $(\sim 3500$ $\left.\mathrm{cm}^{-1}\right)$ to strong $\left(\sim 3100 \mathrm{~cm}^{-1}\right)$ interactions. Intense bands are observed close to $1585 \mathrm{~cm}^{-1}$ and $1440 \mathrm{~cm}^{-1}$, corresponding to the asymmetric and symmetric vibrations of the carboxylate groups $\left[\mathrm{O}-\mathrm{C}-\mathrm{O}^{-}\right]$, respectively. ${ }^{41,42}$ Remarkably, a band at $\sim 1695 \mathrm{~cm}^{-1}$, which has been highlighted in Figure S9 in the SI, becomes apparent upon heating sample LaHPA-I in situ, above $100{ }^{\circ} \mathrm{C}$ (Figure S9 in the SI). This band is likely due to the stretching vibration of carboxylic groups, and its presence suggests that the disordered proton upon heating is localized on the carboxylate groups. Other bands located in the 900-1200 $\mathrm{cm}^{-1}$ region are associated to the phosphonate moieties and they are found in similar metal carboxyphosphonate materials. ${ }^{43}$

MAS NMR Study. The ${ }^{31} \mathrm{P}$ NMR characteristic signal for the tetrahedral $-\mathrm{CPO}(\mathrm{OH})_{2}$ moiety of the phosphonic acids, appearing at $17-20 \mathrm{ppm},{ }^{44,45}$ is shifted, upon metal coordination, to higher field and may be split if different coordination modes coexist. ${ }^{44,46,47}$ The ${ }^{31} \mathrm{P}$ MAS NMR spectrum for LaHPA-II (Figure 9a) is simpler than that of LaHPA-I (Figure 9b).

The former shows two isotropic resonances, at $\sim 14.5 \mathrm{ppm}$ and $\sim 5.0 \mathrm{ppm}$. The appearance of two main signals in the NMR spectrum is consistent with the existence of two crystallographically independent phosphorus atoms, showing different metal-phosphonate connectivities and protonation degrees. Higher connectivity and, hence, lower protonation degree causes greater upfield shifts of the resonance. ${ }^{44,47}$ The fitting of the proton decoupling ${ }^{31} \mathrm{P}$ MAS NMR bands using the program DMFIT ${ }^{20}$ gave a relative contribution $-\mathrm{CPO}_{3} \mathrm{H}^{-} /-$ $\mathrm{CPO}_{3}{ }^{2-}=1 / 1$. These results combined with the crystallographic data are consistent with the proposed general formula $\mathrm{Ln}_{3} \mathrm{H}\left(\mathrm{O}_{3} \mathrm{PCH}(\mathrm{OH}) \mathrm{COO}\right)_{2}\left(\mathrm{HO}_{3} \mathrm{PCH}(\mathrm{OH}) \mathrm{COO}\right)_{2} \cdot 16 \mathrm{H}_{2} \mathrm{O}$.

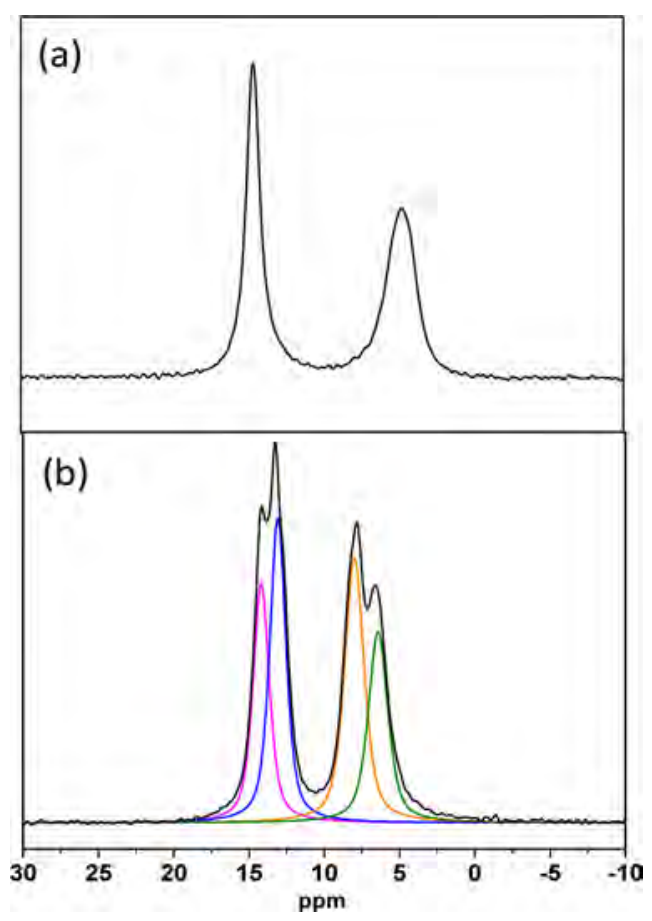

Figure 9. ${ }^{31} \mathrm{P}$ MAS NMR spectrum for (a) LaHPA-II and (b) LaHPAI, showing the fitting for (b).

On this basis, we tentatively assign the low-field ( $14 \mathrm{ppm})$ and the high-field ( $\sim 5 \mathrm{ppm})$ signals to $\mathrm{P} 2$ and $\mathrm{P} 1$, respectively. Figure $9 \mathrm{~b}$ displays the ${ }^{31} \mathrm{P}$ MAS NMR spectrum for LaHPA-I. The corresponding signals are split and that of $\mathrm{P} 1(\sim 7 \mathrm{ppm})$ is shifted to lower field by $\sim 2 \mathrm{ppm}$, when compared to the resonances of LaHPA-II. The split and shift P1 signal in LaHPA-I suggest the existence of slightly different environments and highly distorted phosphorus tetrahedra. The crystallographic study for LaHPA-I shows two average phosphorus positions and the proton disorder is likely the origin of the observed splitting of the phosphorus local environments.

The ${ }^{1} \mathrm{H}$ MAS NMR spectra for samples LaHPA-II and LaHPA-I are shown in Figures 10a and 10b, respectively. They consist of broad bands that can be deconvoluted into several components. For the LaHPA-II spectrum (see Figure 10a), two main signals are observed at $5.8 \mathrm{ppm}$ (broad) and at $5.4 \mathrm{ppm}$ (sharp), which are associated with metal-bound and lattice waters, respectively. ${ }^{48}$ For LaHPA-I (see Figure 10b), these resonances are located at $\sim 5.5 \mathrm{ppm}$ (very broad) and $\sim 4.9$ ppm (sharp). The resonances located at $8.4 \mathrm{ppm}$ and $2.4 \mathrm{ppm}$ are typical of the protons of hydrogen phosphonate $\left(-\mathrm{CPO}_{3} \mathrm{H}\right)$ and hydroxyl $(-\mathrm{HCOH})$ groups, respectively. For LaHPA-I, these bands are situated at $8.6 \mathrm{ppm}$ and $1.5 \mathrm{ppm}$, respectively. In addition, the spectrum for LaHPA-II (see Figure 10a) contains another resonance at $13.2 \mathrm{ppm}$ that may be attributed to proton of the carboxylic group. This band is virtually absent in LaHPA-I, showing that the hydrogen disorder is different in the two series, which agrees with the ${ }^{31} \mathrm{P}$ NMR data discussed above.

Taking together the ${ }^{1} \mathrm{H}$ and ${ }^{31} \mathrm{P}$ NMR data, some information about the structurally nonlocalized proton, $\mathrm{Ln}_{3} \mathrm{H}\left(\mathrm{O}_{3} \mathrm{PCH}(\mathrm{OH}) \mathrm{COO}\right)_{2}\left(\mathrm{HO}_{3} \mathrm{PCH}(\mathrm{OH}) \mathrm{COO}\right)_{2} \cdot 16 \mathrm{H}_{2} \mathrm{O}$, may be inferred. The NMR results suggest that this proton may be preferentially associated to a carboxylate group in LaHPA-II, 


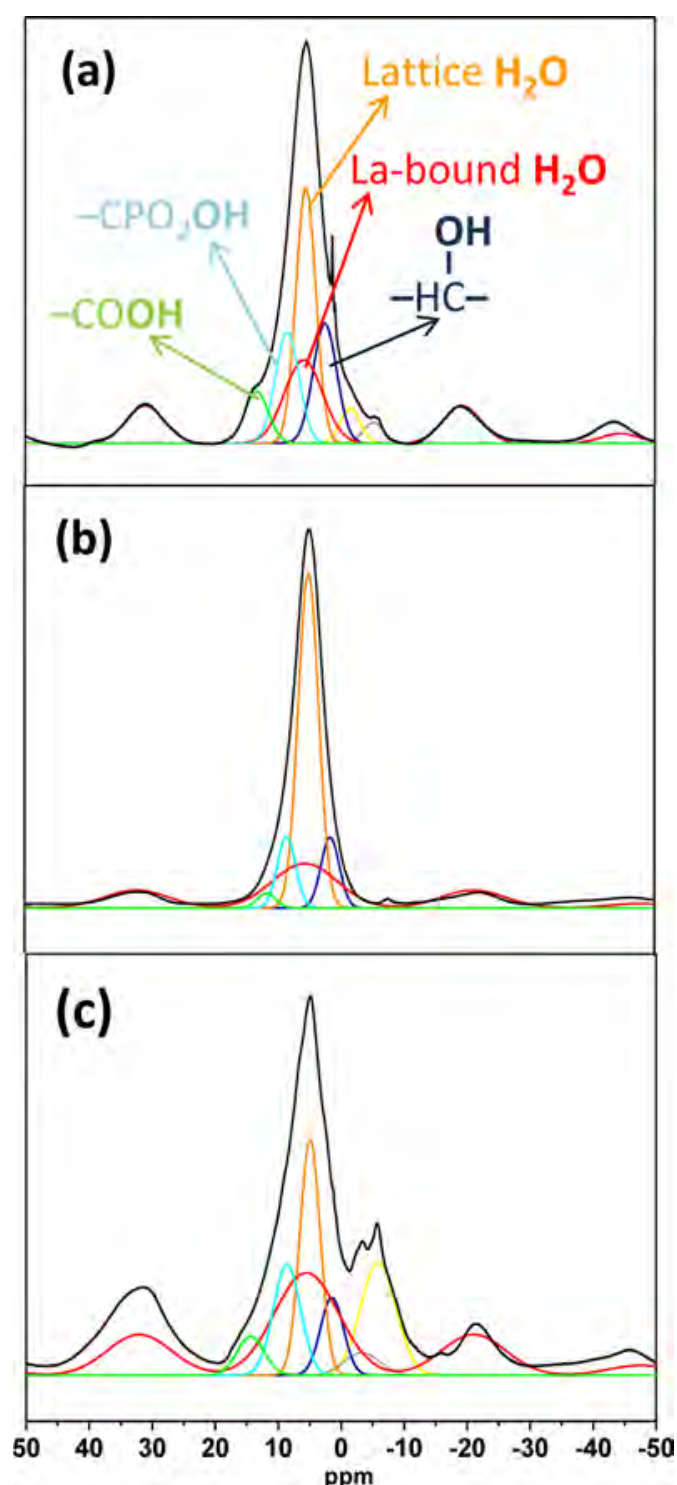

Figure 10. ${ }^{1} \mathrm{H}$ MAS NMR spectra, showing the fitting to several components for (a) LaHPA-II, (b) LaHPA-I at room temperature; (c) LaHPA-I heated at $80^{\circ} \mathrm{C}$. for $60 \mathrm{~min}$. The bands situated close to -5 $\mathrm{ppm}$ are due to the signal probe and they are more conspicuous in panel c.

resonance at $\sim 13 \mathrm{ppm}$, and to one phosphonate group, $\sim 8$ ppm, for LaHPA-I.

Additional information was obtained by recording the ${ }^{1} \mathrm{H}$ MAS NMR spectrum for LaHPA-I after heating (see Figure 10c). As expected, dehydration causes the intensity of the signal associated with the lattice water (sharp band at $\sim 5.5 \mathrm{ppm}$ ) to decrease abruptly. As a result, the relative contribution of the signal due to the lanthanum-bound water (very broad band at $\sim 6 \mathrm{ppm}$ ) increases notably. Very interestingly, the intensity of the resonance at $14.4 \mathrm{ppm}$ increases in the partially dehydrated LaHPA-I which may be attributed to the proton of a $-\mathrm{COOH}$ group. Therefore, partial dehydration profoundly affects the position of the disordered proton which departs from the phosphonic and approaches the carboxylate group. This carboxylic resonance is very similar to that observed for LaHPA-II, as discussed above. The localization of the disordered hydrogens close to carboxylic group in the trimers, after partial LaHPA-I dehydration, may justify the conversion to LaHPA-II upon rehydration.

Proton-Conductivity Study. The presence of $1 \mathrm{D}$ channels, filled with water molecules, in the crystal structures of both series (see Figure 6), suggests the possibility of proton conductivity behavior. Furthermore, there are certain structural features that make these good candidates as proton-conductors at room temperature. These include the $-\mathrm{POH}$ groups pointing toward the interior of the channels, the network of hydrogen bonds within the channels and the proximity between the lattice water molecules. Therefore, conductivity studies have been carried out for one representative member of each series. Impedance spectra for GdHPA-II and LaHPA-I at different relative humidity (\%RH) values and temperatures were collected, and they are shown in the Figures S10 and S11, respectively, in the SI.

When GdHPA-II is exposed to the highest \%RH value of $98 \%$, a spike is observed which has an associated capacitance of $\sim 1 \mu \mathrm{F}$. Since the spike is inclined to the $Z^{\prime}$ axis by $\sim 70^{\circ}$, see Figure S10, it indicates a partial-blocking electrode response that allows limited diffusion; therefore, the conducting species must be ionic (i.e., $\mathrm{H}^{+}$ions). The total pellet resistance $\left(R_{\mathrm{T}}\right)$ was obtained from the intercept of the spike and/or the arc (low frequency end) on the $Z^{\prime}$ axis. At $98 \% \mathrm{RH}$ and $T=21{ }^{\circ} \mathrm{C}$, $\sigma_{\mathrm{T}}$ was $3.2 \times 10^{-4} \mathrm{~S} \mathrm{~cm}^{-1}$. This value is larger than those values recently reported for some metal phosphonate $\mathrm{MOF}$ materials- $\sigma \approx(3.5-5) \times 10^{-5} \mathrm{~S} \mathrm{~cm}^{-1}$ at $25{ }^{\circ} \mathrm{C}$ and $95-$ $98 \% \mathrm{RH},{ }^{10 c, 49}$ - but slightly lower than those reported by us for magnesium $^{50 a}$ and lanthanum ${ }^{50 b}$ tetraphosphonates $(\sigma=1.6 \times$ $10^{-3} \mathrm{~S} \mathrm{~cm}^{-1}$ and $8 \times 10^{-3} \mathrm{~S} \mathrm{~cm}^{-1}$, respectively, measured under similar conditions). These last values are on the same order than that reported for $\left(\mathrm{NH}_{4}\right)_{2}(\mathrm{adp})\left[\mathrm{Zn}_{2}(\mathrm{ox})_{3}\right] \cdot 3 \mathrm{H}_{2} \mathrm{O}(\mathrm{adp}=$ adipic acid), which shows the highest proton conductivity $(\sigma \approx$ $8 \times 10^{-3} \mathrm{~S} \mathrm{~cm}^{-1}$ at $25{ }^{\circ} \mathrm{C}$ and $\left.98 \% \mathrm{RH}\right) .{ }^{10 f}$ When reducing the $\mathrm{RH}$ values, the overall conductivity values decrease, as expected for proton conductors (see Figure S10 in the SI).

Proton conductivity properties were also measured for LaHPA-I. The overall behavior was similar, but the conductivity values were $\sim 2$ orders of magnitude lower than those of series II. LaHPA-I sample took much more time to equilibrate at a given water partial pressure. As an example, the proton conductivity $\left(\sigma_{\mathrm{T}}\right)$ for LaHPA-I was $5.6 \times 10^{-6} \mathrm{~S} \mathrm{~cm}^{-1}$ at $98 \% \mathrm{RH}$ and $\mathrm{T}=21{ }^{\circ} \mathrm{C}$. Selected conductivity plots are given in Figure S11 in the SI.

The overall pellet conductivities for GdHPA-II, in traditional Arrhenius format, are given in Figure 11 for two \%RH values. The derived activation energies for the conduction process were 0.23 and $0.49 \mathrm{eV}$ for $98 \% \mathrm{RH}$ and $69 \% \mathrm{RH}$, respectively. These reported activation energies are located within the range typically attributed to a Grotthuss transfer mechanism via water molecules $(0.1-0.4 \mathrm{eV}){ }^{51}$ The increase in activation energy when decreasing the water partial pressure is very likely related to a decrease in the water content within the channels (see above). The overall pellet conductivities for LaHPA-I, in traditional Arrhenius format, are given in Figure S12 in the SI. The derived activation energies are similar and close to $0.20 \mathrm{eV}$.

Photoluminescence Characterization. Initially, a steadystate luminescence study was undertaken. The emission spectra for LnHPA-II samples, with different loadings of $\mathrm{Eu}$, after excitation at $370 \mathrm{~nm}$ and recorded at room temperature display the characteristic sharp lines assigned to transitions between the first excited nondegenerate ${ }^{5} \mathrm{D}_{0}$ state and the ${ }^{7} \mathrm{~F}_{0-4}$ levels of the fundamental septet (see Figure 12). Similar spectrum profiles 


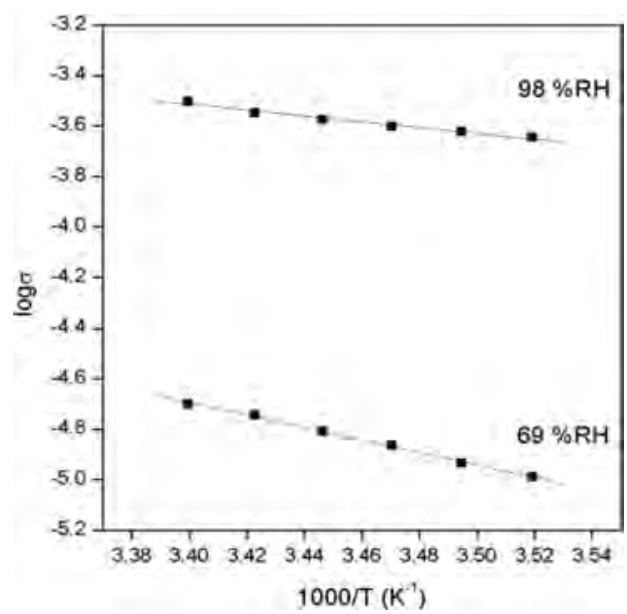

Figure 11. Conductivity values as function of temperature (Arrhenius format) for GdHPA-II at two relative humidities.

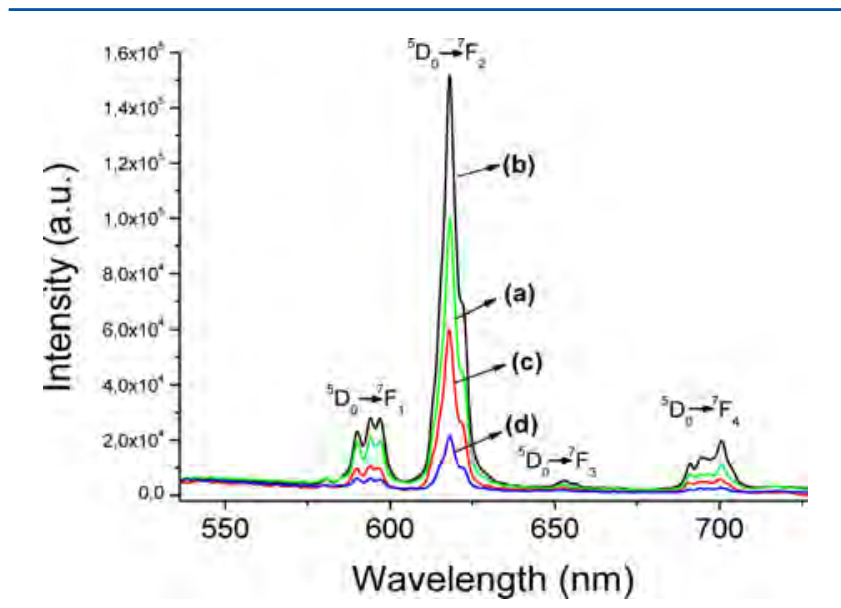

Figure 12. Room-temperature emission spectra for Eu-containing derivatives of series II: (a) EuHPA-II, (b) $\mathrm{Eu}_{0.9} \mathrm{~Tb}_{0.1} \mathrm{HPA}$, (c) $\mathrm{Eu}_{0.95} \mathrm{~Tb}_{0.05} \mathrm{HPA}$, and (d) $\mathrm{Gd}_{0.95} \mathrm{Eu}_{0.05} \mathrm{HPA}$. The excitation wavelength was $370 \mathrm{~nm}$.

have been obtained for the studied samples, $\mathrm{Eu}_{0.95} \mathrm{~Tb}_{0.05} \mathrm{HPA}$, $\mathrm{Eu}_{0.9} \mathrm{~Tb}_{0.1} \mathrm{HPA}$, and $\mathrm{Gd}_{0.95} \mathrm{Eu}_{0.05} \mathrm{HPA}$, but with different emission intensities (see Figure 12).

In order to understand the role of the water coordination in the structure, EuHPA-II was dehydrated at $110{ }^{\circ} \mathrm{C}$ for $60 \mathrm{~min}$ observing a blue shift of $5 \mathrm{~nm}$ for the transition ${ }^{5} \mathrm{D}_{0} \rightarrow{ }^{7} \mathrm{~F}_{2}$ (see Figure 13). This blue shift can be assigned to the modification of the coordination sphere around the $\mathrm{Eu}^{3+}$ centers. The presence of a shoulder at $612 \mathrm{~nm}$ in the dehydrated sample suggests that still some water remains around Eu centers. The reversibility of the dehydration-rehydration process for the partly dehydrated EuHPA-II was studied by exposing this sample to a water-saturated atmosphere. Then, the emission spectra were taken upon different times of exposure to the moisture. The characteristic emission bands show a reversible behavior with an isosbestic point located at $615 \mathrm{~nm}$.

Second, luminescence lifetime measurements were carried out. Lifetime values were obtained by monitoring the temporal profile of the ${ }^{5} \mathrm{D}_{0} \rightarrow{ }^{7} \mathrm{~F}_{2}$ transition. The decay curves monitored at $618 \mathrm{~nm}$ can be fitted as a monoexponential curve. At room temperature, all the samples show similar behavior with a lifetime decay of $\sim 262 \mu$ s (see Figure S13 in the SI). The sample $\mathrm{Gd}_{0.95} \mathrm{Eu}_{0.05} \mathrm{HPA}$ shows slightly slower signal decay,

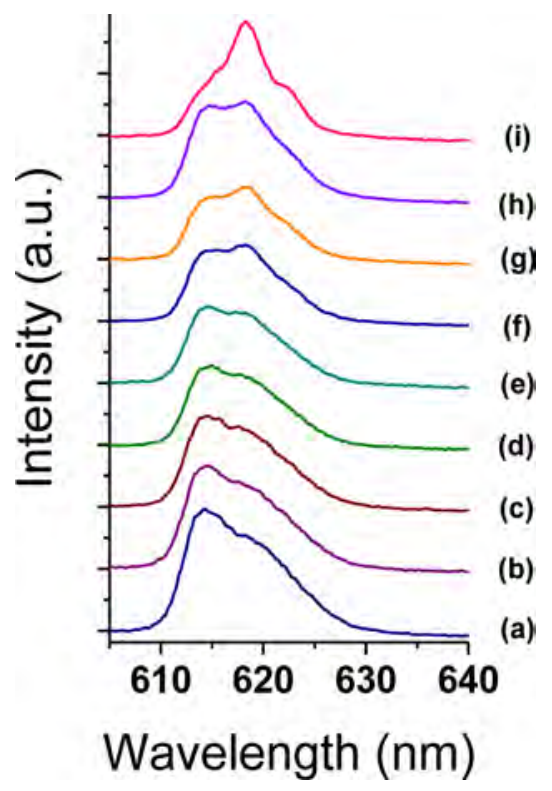

Figure 13. Evolution of the emission spectra of the transition ${ }^{5} \mathrm{D}_{0} \rightarrow{ }^{7} \mathrm{~F}_{2}$ at room temperature of dehydrated EuHPA-II sample after exposition to moisture for different times: (a) dry sample, (b) $10 \mathrm{~min}$, (c) $30 \mathrm{~min}$, (d) $50 \mathrm{~min},(\mathrm{e}) 70 \mathrm{~min},(\mathrm{f}) 90 \mathrm{~min},(\mathrm{~g}) 100 \mathrm{~min},(\mathrm{~h}) 120 \mathrm{~min}$, and (i) $180 \mathrm{~min}$. The excitation wavelength was $370 \mathrm{~nm}$.

probably due to lower contribution of nonraditative paths to ${ }^{5} \mathrm{D}_{0}$ depopulation as $\mathrm{Eu}-\mathrm{Eu}$ pairs become less probable.

The reversibility of the dehydration process was studied in detail by considering the temporal profiles of the dehydrated EuHPA-II sample and subsequently exposed to moisture. After EuHPA-II was dehydrated at $110{ }^{\circ} \mathrm{C}$ for $60 \mathrm{~min}$, its signal lifetime increases from $262 \mu \mathrm{s}$ in the original sample to $417 \mu \mathrm{s}$ in the partly dehydrated material. The reversible behavior was proven when the sample was exposed to a saturated water atmosphere. The lifetime decreases with the exposition time to moisture (see Figure 14). It may be possible to estimate the number of Eu-bound water molecules by the previously reported $^{6 c, d}$ formula:

$$
n=1.05 \times \tau_{\mathrm{H}_{2} \mathrm{O}}{ }^{-1}-0.70
$$

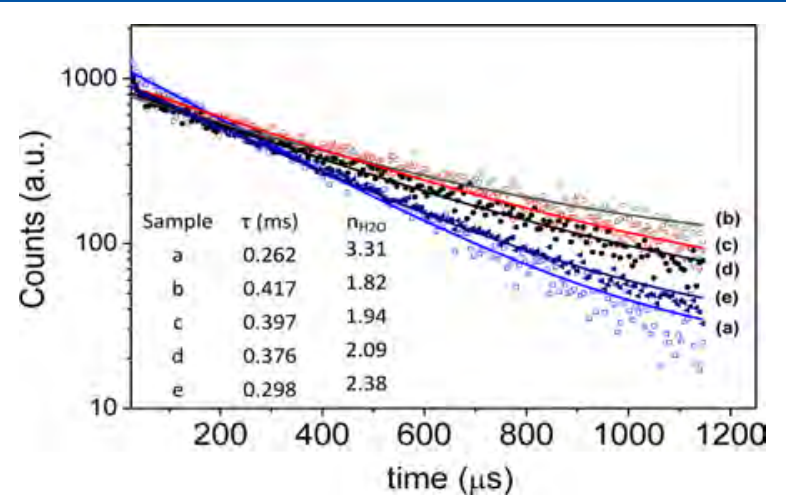

Figure 14. Room-temperature emission decays for EuHPA-II: (a) fresh sample, (b) after drying for $60 \mathrm{~min}$ at $110^{\circ} \mathrm{C}$, (c) sample exposed to a saturated water atmosphere for $10 \mathrm{~min}$, (d) for $60 \mathrm{~min}$ and (e) for $120 \mathrm{~min}$. The excitation wavelength was $370 \mathrm{~nm}$ and monitored at $618 \mathrm{~nm}$. 
The inset of Figure 14 gives a table with the ${ }^{5} \mathrm{D}_{0}$ lifetime and the average calculated number of water molecules coordinated to $\mathrm{Eu}$ emission centers. It can be seen that the calculated number of Eu-bound water molecules (3.31), from this very simple approach, is not far from the average value expected from the structural determination (2.67). This value is the multiplicity-averaged value of $\mathrm{Eu} 1\left(\mathrm{H}_{2} \mathrm{O}\right)_{4}$ and $\mathrm{Eu} 2\left(\mathrm{H}_{2} \mathrm{O}\right)_{2}$, with Eu1 having half multiplicity than Eu2. Upon heating, EuHPA-II loses $\sim 1.5$ water molecules per Eu site upon dehydration at 110 ${ }^{\circ} \mathrm{C}$. Then, the number of Eu-coordinated water molecules increases as the exposure time to atmospheric moisture increases, but the fully hydrated EuHPA sample is not recovered after exposure to water moisture for $120 \mathrm{~min}$.

Finally, the behavior of the water with temperature for openframework EuHPA-II derived from the luminescence study is fully consistent with the TGA-DTA and thermodiffractometric studies. In the investigated experimental conditions, it was not possible to isolate the water-evacuated channels without removing water from the lanthanum first-coordination sphere. The removal of water molecules linked to Ln sites provokes the amorphization of this open-framework structure, and then no adsorption capacity is observed in the fully dehydrated EuHPAII sample.

\section{CONCLUSION}

Recently, intense efforts are devoted to produce lanthanide MOF materials exhibiting unique cooperative multifunctionality. Phosphonate-based MOFs are at the epicenter of a field that is far from ripe, presenting a multitude of opportunities and challenges. Within this general framework, here, we have reported a full new family of Ln-based 3D MOFs ( $\mathrm{Ln}=\mathrm{La}, \mathrm{Ce}$, Pr, Sm, Eu, Gd, Tb, and Dy) with the ligand 2hydroxyphosphonoacetate. The principal conclusions can be summarized as follows:

(1) Compounds LnHPA, with the formula $\mathrm{Ln}_{3}\left(\mathrm{H}_{0.75} \mathrm{O}_{3} \mathrm{PCHOHCOO}\right)_{4} \cdot x \mathrm{H}_{2} \mathrm{O}(x=15-16)$ crystallize in the orthorhombic system. Two types of structures can be isolated: series I and II polymorphs. Series I compounds crystallize in a noncentrosymmetric structure (e.g., Iba2), whereas series II samples crystallize in a centrosymmetric structure (e.g., Pcan).

(2) Synthesis $\mathrm{pH}$ plays a significant role on the identity of the products. For example, for the La derivative, the polymorphic phase LaHPA-I was obtained for $\mathrm{pH}$ values of $<0.8$, whereas LaHPA-II was prepared at $\mathrm{pH}$ values of $>1.0$. Syntheses at intermediate $\mathrm{pH}$ values led to a mixture of these phases.

(3) For both series I and II polymorphs, the 3D frameworks result from the linkage of organic-inorganic layers by central lanthanide cations, which yield trimeric SBUs also found in several other metal-HPA hybrids. Large ovalshaped $1 \mathrm{D}$ channels, running along the $c$-axis, are formed by the spatial separation of the layers and filled with lattice water molecules.

(4) LnHPA compounds show crystalline-to-amorphous-tocrystalline transformations, upon dehydration-rehydration processes.

(5) LnHPA materials also show proton conductivity. For example, for LaHPA (series I), $\sigma_{\mathrm{T}}=5.6 \times 10^{-6} \mathrm{~S} \mathrm{~cm}^{-1}$ and for GdHPA (series II), $\sigma_{\mathrm{T}}=3.2 \times 10^{-4} \mathrm{~S} \mathrm{~cm}^{-1}$, both at $98 \% \mathrm{RH}$ and $\mathrm{T}=21{ }^{\circ} \mathrm{C}$.
(6) Photoluminescence results, including lifetime measurements, indicate that the dehydration-rehydration of emitting $\mathrm{Eu}$ centers is reversible. The Eu-bound water content can be estimated by a simple approach from the luminescence lifetimes.

\section{ASSOCIATED CONTENT}

\section{Supporting Information}

CIF files for LaHPA-I, LaHPA-II, CeHAP-I, GdHPA-II, and TbHPA-II. Figures S1-S4: PXRD Rietveld plots for LaHPA-I, LaHPA-II, CeHAP-I, and TbHPA-II, respectively. Figure S5: View of a hybrid organo-inorganic layer for GdHPA-II. Figures S6 and S7: thermodiffractometric data for LaHPA-I and GdHPA-II. Figure S8: IR spectra for selected LnHPA compounds. Figure S9: IR spectra for LnHPA-I in situ heated at selected temperatures. Figure $S 10$ and S11: Complex impedance plane plots for GdHPA-II and LaHPA-I under different RH values. Figure S12: Proton conductivity Arrhenius plots for LaHPA-I. Figure S13: Room-temperature emission decay curves for some Eu-containing hybrids. Table S1: Unit cell parameters for LnHPA-I and LnHPA-II compounds. This material is available free of charge via the Internet at http:// pubs.acs.org.

\section{AUTHOR INFORMATION}

\section{Corresponding Author}

*E-mail addresses: aurelio@uma.es (A.C.), demadis@ chemistry.uoc.gr (K.D.D.).

\section{Author Contributions}

The manuscript was written through contributions of all authors. All authors have given approval to the final version of the manuscript.

\section{Funding}

The work at UMA was funded by MAT2010-15175 research grant (Spain), which is cofunded by FEDER. The work at the UoC was supported by a grant from the Research Committee of the University of Crete, ELKE, (KA 3517). The project "Factoría de Crystalización, CONSOLIDER INGENIO-2010" provided X-ray structural facilities for this work.

\section{Notes}

The authors declare no competing financial interest.

\section{ACKNOWLEDGMENTS}

We thank synchrotron beamtime at the Spanish-CRG BM16 Beamline (ESRF-Grenoble, France).

\section{ABBREVIATIONS}

Ln = lanthanide ion; $\mathrm{H}_{3} \mathrm{HPA}=$ hydroxyphosphonoacetic acid; $\mathrm{SBU}=$ secondary building unit; s.g = space group; $\mathrm{RH}=$ relative humidity

\section{REFERENCES}

(1) (a) Special thematic issue on Metal Organic Frameworks, Chem. Rev. 2012, 112 (2), 673-1268. (b) Special Thematic Issue on Hybrid Materials, Chem. Soc. Rev. 2011, 40 (2), 453-1152. (c) Themed issue on Metal-Organic Frameworks, Chem. Soc. Rev. 2009, 38, 1201.

(2) (a) Metal-Organic Frameworks. Applications from Catalysis to Gas Storage, Farrusseng, D., Ed.; Wiley-VCH Verlag \& Co. KGaA: Weinheim, Germany, 2011. (b) Metal-Organic Frameworks. Design and Application; MacGillivray, L., Ed.; Wiley-VCH Verlag \& Co. KGaA: Weinheim, Germany, 2011. 
(3) (a) Ma, L. Q.; Lin, W. B. In Functional Metal-Organic Frameworks: Gas Storage, Separation and Catalysis, Schroder, M. Ed.; Topics in Current Chemistry, Vol. 293; Springer: Berlin, 2010; p 175. (b) Ma, S.; Yuan, D.; Wang, X.-S.; Zhou, H.-C. Inorg. Chem. 2009, 48, 2072. (c) Devic, T.; Serre, C.; Audebrand, N.; Marrot, J.; Férey, G. J. Am. Chem. Soc. 2005, 127, 12788. (d) Chandler, B. D.; Yu, J. O.; (e) Hamon, L.; Heymans, N.; Llewellyn, P. L.; Guillerm, V.; Ghoufi, A.; Vaesen, S.; Maurin, G.; Serre, C.; De Weireld, G.; Pirngruber, G. D. Dalton Trans. 2012, No. 41, 4052. (f) Cramb, D. T.; Shimizu, G. K. H. Chem. Mater. 2007, 19, 4467.

(4) (a) Kido, J.; Okamoto, Y. Chem. Rev. 2002, 102, 2357. (b) Marques, N.; Sella, A.; Takats, J. Chem. Rev. 2002, 102, 2137. (c) Paz, F. A. A.; Klinowski, J.; Vilela, S. M. F.; Tome, J. P. C.; Cavaleiro, J. A. S.; Rocha, J. Chem. Soc. Rev. 2012, 41, 1088. (d) Guo, X.; Zhu, G.; Li, Z.; Chen, Y.; Li, X.; Qiu, S. Inorg. Chem. 2006, 45, 4065. (e) Zhang, W.; Xiong, R.-G. Chem. Rev. 2012, 112, 1163.

(5) (a) Ma, L. Q.; Abney, C.; Lin, W. B. Chem. Soc. Rev. 2009, 38, 1248. (b) Cunha-Silva, L.; Lima, S.; Ananias, D.; Silva, P.; Mafra, L.; Carlos, L. D.; Pillinger, M.; Valente, A. A.; Paz, F. A. A.; Rocha, J. J. Mater. Chem. 2009, 19, 2618. (c) Cirujano, F. G.; Llabrés i Xamena, F. X.; Corma, A. Dalton Trans. 2012, No. 41, 4249. (d) Crassous, J. Chem. Soc. Rev. 2009, 38, 830.

(6) (a) Rocha, J.; Carlos, L. D.; Almeida Paz, F. A.; Ananias, D. Chem. Soc. Rev. 2011, 40, 926. (b) Ma, S.; Yuan, D.; Wang, X.-S.; Zhou, H.-C. Inorg. Chem. 2009, 48, 2072. (c) Harbuzaru, B. V.; Corma, A.; Rey, F.; Atienzar, P.; Jordá, J. L.; García, H.; Ananias, D.; Carlos, L. D.; Rocha, J. Angew. Chem., Int. Ed. 2008, 47, 1080. (d) Harbuzaru, B. V.; Corma, A.; Rey, F.; Jordá, J. L.; Ananias, D.; Carlos, L. D.; Rocha, J. Angew. Chem., Int. Ed. 2009, 48, 6476. (e) Ma, J.-C.; Liu, Y.-Y.; Yang, J.; Liu, Y.-Y.; Ma, J.-F. CrystEngComm 2011, 13, 3498. (f) Hix, G. B. In Metal Phosphonate Chemistry: From Synthesis to Applications; Clearfield, A., Demadis, K. D., Eds.; The Royal Society of Chemistry: London, 2012; Chapter 16, p 525. (g) Rao, X. T.; Huang, Q.; Yang, X. L.; Cui, Y. J.; Yang, Y.; Wu, C. D.; Chen, B. L.; Qian, G. D. J. Mater. Chem. 2012, 22, 3210. (h) Zhou, X.; Guo, Y.; Shi, Z.; Song, X.; Tang, X.; Hu, X.; Zhu, Z.; Li, P.; Liu, W. Dalton Trans. 2012, No. 41, 1765.

(7) Cui, Y. J.; Yue, Y. F.; Qian, G. D.; Chen, B. L. Chem. Rev. 2012, $112,1126$.

(8) (a) Achmann, S.; Hagen, G.; Kita, J.; Malkowsky, I. M.; Kiener, C.; Moos, R. Sensors 2009, 9, 1574. (b) Ohba, R. Intelligent Sensor Technology; Wiley: Chichester, U.K., 1992; p 140. (c) Kreno, L. E.; Leong, K.; Farha, O. K.; Allendorf, M.; Van Duyne, R. P.; Hupp, J. T. Chem. Rev. 2012, 112, 1105.

(9) (a) Ho, C.-L.; Wong, W. Y. Coord. Chem. Rev. 2011, 255, 2469. (b) Chou, P. T.; Chi, Y.; Chung, M. W.; Lin, C. C. Coord. Chem. Rev. 2011, 255, 2653.

(10) (a) Alberti, G.; Casciola, M. Solid State Ionics 2001, 145, 3. (b) Shimizu, G. K. H.; Taylor, J. M.; Dawson, K. W. In Metal Phosphonate Chemistry: From Synthesis to Applications; Clearfield, A., Demadis, K. D., Eds.; The Royal Society of Chemistry: London, 2012; Chapter 15, p 493. (c) Costantino, F.; Donnadio, A.; Casciola, M. Inorg. Chem. 2012, 51, 6992. (d) Jeong, N. C.; Samanta, B.; Lee, C. Y.; Farha, O. K.; Hupp, J. T. J. Am. Chem. Soc. 2012, 134, 51. (e) Sadakiyo, M.; Okawa, H.; Shigematsu, A.; Ohba, M.; Yamada, T.; Kitagawa, H. J. Am. Chem. Soc. 2012, 134, 5472. (f) Sadakiyo, M.; Yamada, T.; Kitagawa, H. J. Am. Chem. Soc. 2009, 131, 9906. (g) Hurd, J. A.; Vaidhyanathan, R.; Thangadurai, V.; Ratcliffe, C. I.; Moudra-kovski, I. M.; Shimizu, G. K. H. Nat. Chem. 2009, 1, 705. (h) Sahoo, S. C.; Kundu, T.; Banerjee, R. J. Am. Chem. Soc. 2011, 133, 17950. (i) Shigematsu, A.; Yamada, T.; Kitagawa, H. J. Am. Chem. Soc. 2011, 133, 2034. (j) Mallick, A.; Kundu, T.; Banerjee, R. Chem. Commun. 2012, 48, 8829 .

(11) Metal Phosphonate Chemistry: From Synthesis to Applications; Clearfield, A., Demadis, K. D., Eds.; The Royal Society of Chemistry: London, 2012.

(12) (a) Mao, J.-G. Coord. Chem. Rev. 2007, 251, 1493. (b) Zhang, N.; Sun, Z.; Zhu, Y.; Zhang, J.; Liu, L.; Huang, C.; Lu, X.; Wang, W.; Tong, F. New J. Chem. 2010, 34, 2429. (c) Pawlicki, G.; Lis, S. Opt. Mater. 2011, 33, 1544. (d) Wang, R.-C.; Zhang, Y.; Hu, H.; Frausto, R.
R.; Clearfield, A. Chem. Mater. 1992, 4, 864. (e) Ying, S.-M.; Zeng, X.R.; Fang, X.-N.; Li, X.-F.; Liu, D.-S. Inorg. Chim. Acta 2006, 359, 1589. (f) Bauer, S.; Bein, T.; Stock, N. J. Solid State Chem. 2006, 179, 145.

(13) Li, J.-T.; Zheng, L. M. Inorg. Chim. Acta 2009, 362, 1739.

(14) Colodrero, R. M. P.; Cabeza, A.; Olivera-Pastor, P.; Papadaki, M.; Rius, J.; Choquesillo-Lazarte, D.; García-Ruiz, J. M.; Demadis, K. D.; Aranda, M. A. G. Cryst. Growth Des. 2011, 11, 1713.

(15) Demadis, K. D.; Papadaki, M.; Cisarova, I. ACS Appl. Mater. Interfaces 2010, 2, 1814.

(16) Sun, Z.-G.; Chen, H.; Liu, Z.-M.; Cui, L.-Y.; Zhu, Y.-Y.; Zhao, Y.; Zhang, J.; You, W.-S.; Zhu, Z.-M. Inorg. Chem. Commun. 2007, 10, 283.

(17) Lodhia, S.; Turner, A.; Papadaki, M.; Demadis, K. D.; Hix, G. B. Cryst. Growth Des. 2009, 9, 1811.

(18) Colodrero, R. M. P.; Olivera-Pastor, P.; Cabeza, A.; Papadaki, M.; Demadis, K. D.; Aranda, M. A. G. Inorg. Chem. 2010, 49, 761.

(19) (a) Stock, N.; Biswas, S. Chem. Rev. 2012, 112, 933-969. (b) Zhao, Y. G.; Li, K. H.; Li, J. Z. Naturforsch. 2010, 65, 976-998.

(20) Massiot, D.; Fayon, F.; Capron, M.; King, I.; Le Calvé, S.; Alonso, B.; Durand, J.-O.; Bujoli, B.; Gan, Z.; Hoatson, G. Magn. Reson. Chem. 2002, 40, 70

(21) Boultif, A.; Louer, D. J. Appl. Crystallogr. 2004, 37, 724.

(22) Cabeza, A.; Losilla, E. R.; Martínez-Tapia, H. S.; Bruque, S.; Aranda, M. A. G. Adv. X-ray Anal. 2000, 42, 228.

(23) Agilent Technologies. CrysAlisPro, Version 1.171.35.19 (release 27-10-2011 CrysAlis171.NET) (compiled Oct. 27, 2011, 15:02:11).

(24) Sheldrick, G. M. Acta Crystallogr., Sect. A: Found. Crystallogr. 2008, A64, 112.

(25) Spek, A. L. J. Appl. Crystallogr. 2003, 36, 7.

(26) Sheldrick, G. M. SADABS, Program for Empirical Absorption Correction of Area Detector Data; University of Göttingen: Göttingen, Germany, 1997.

(27) Sheldrick, G. M. Acta Crystallogr., Sect. A: Found. Crystallogr. 1990, 46A, 467.

(28) Sheldrick, G. M. SHELXL-97, Program for the Refinement of Crystal Structures; University of Göttingen: Göttingen, Germany, 1997.

(29) Rietveld, H. M. J. Appl. Crystallogr. 1969, 2, 65.

(30) Larson, A. C.; Von Dreele, R. B. General Structure Analysis System (GSAS); Los Alamos National Laboratory, Los Alamos, NM, Report No. LAUR 86-748, 2004.

(31) Toby, B. H. J. Appl. Crystallogr. 2001, 34, 210.

(32) Shannon, R. D.; Prewitt, C. T. Acta Crystallogr., Sect. B: Struct. Crystallogr. Cryst. Chem. 1969, B25, 925.

(33) Dubinin, M.; Radushkevich, L. V. Proc. Acad. Sci. USSR 1947, $55,331$.

(34) winDETA; Novocontrol GmbH: Hundsangen, Germany, 1995.

(35) Stavgianoudaki, N.; Papathanasiou, K. E.; Colodrero, R. M. P.; Choquesillo-Lazarte, D.; Garcia-Ruiz, J. M.; Cabeza, A.; Aranda, M. A. G.; Demadis, K. D. CrystEngComm. 2012, 14, 5385.

(36) Irwin, A. E.; DeRamos, C. M.; Stout, B. E. In Humic and Fulvic Acids: Isolation, Structure, and Environmental Role; Gaffney, J. S., Marley, N. A., Clark, S. B., Eds.; ACS Symposium Series, Vol. 651; American Chemical Society: Washington, DC, 1996; p 244.

(37) (a) Colodrero, R. M. P.; Olivera-Pastor, P.; Cabeza, A.; Papadaki, M.; Demadis, K. D.; Aranda, M. A. G. Inorg. Chem. 2010, 49, 761. (b) Fu, R.; Hu, S.; Wu, X. J. Solid State Chem. 2011, 184, 945. (c) Fu, R.; Hu, S.; Wu, X. Dalton Trans. 2009, 9440.

(38) Zhang, N.; Huang, C.-Y.; Sun, Z.-G.; Liu, L.; Hua, R.-N.; Lu, X.; Tong, F.; Wang, W.-N. Z. Anorg. Allg. Chem. 2010, 636, 449.

(39) Colodrero, R. M. P.; Cabeza, A.; Olivera-Pastor, P.; Papadaki, M.; Rius, J.; Choquesillo-Lazarte, D.; García-Ruiz, J. M.; Demadis, K. D.; Aranda, M. A. G. Cryst. Growth Des. 2011, 11, 1713.

(40) Sun, Z.; Chen, H.; Liu, Z.; Cui, L.; Zhu, Y.; Zhao, Y.; Zhang, J.; You., W.; Zhu, Z. Inorg. Chem. Commun. 2007, 10, 283.

(41) Demadis, K. D.; Papadaki, M.; Raptis, R. G.; Zhao, H. Chem. Mater. 2008, 20, 4835 .

(42) Gómez-Alcantara, M. M.; Aranda, M. A. G.; Olivera-Pastor, P.; Beran, P.; García-Muñoz, J. L.; Cabeza, A. Dalton Trans. 2006, 577. 
(43) Gómez-Alcántara, M. M.; Cabeza, A.; Aranda, M. A. G.; Guagliardi, A.; Mao, J. G.; Clearfield, A. Solid State Sci. 2004, 6, 479. (44) Gomez-Alcantara, M. M.; Cabeza, A.; Olivera-Pastor, P.; Fernandez-Moreno, F.; Sobrados, I.; Sanz, J.; Morris, R. E.; Clearfield, A.; Aranda, M. A. G. Dalton Trans. 2007, 2394.

(45) Grossmann, G.; Grossmann, A.; Ohms, G.; Breuer, E.; Chen, R.; Golomb, G.; Cohen, H.; Hägele, G.; Classen, R. Magn. Reson. Chem. 2000, 28, 11 .

(46) Cabeza, A.; Aranda, M. A. G.; Bruque, S.; Poojary, D. M.; Clearfield, A.; Sanz, J. Inorg. Chem. 1998, 37, 4168.

(47) Cabeza, A.; Gomez-Alcantara, M. M.; Olivera-Pastor, P.; Sobrados, I.; Sanz, J.; Xiao, B.; Morris, R. E.; Clearfield, A.; Aranda, M. A. G. Microporous Mesoporous Mater. 2008, 114, 322.

(48) (a) Sanz, J.; Soria, J.; Sobrados, I.; Yurdakal, S.; Augugliaro, V. J. Phys. Chem. C 2012, 116, 5110. (b) Weihe, M.; Hunger, M.; Breuninger, M.; Karge, H. G.; Weitkamp, J. J. Catal. 2001, 198, 256.

(49) Taylor, J. M.; Mah, R. K.; Moudrakovski, I. L.; Ratcliffe, C. I.; Vaidhyanathan, R.; Shimizu, G. K. H. J. Am. Chem. Soc. 2010, 132, 14055.

(50) (a) Colodrero, R. M. P.; Olivera-Pastor, P.; Losilla, E. R.; Hernández-Alonso, D.; Aranda, M. A. G.; Leon-Reina, L.; Rius, J.; Demadis, K. D.; Moreau, B.; Villemin, D.; Palomino, M. I.; Rey, F.; Cabeza, A. Inorg. Chem. 2012, 51, 7689. (b) Colodrero, R. M. P.; Olivera-Pastor, P; Losilla, E. R.; Aranda, M. A. G.; León-Reina, L.; Papadaki, M.; McKinlay, A. C.; Morris, R. E.; Demadis, K. D.; Cabeza, A. Dalton Trans. 2012, No. 41, 4045.

(51) Colomban, P. Proton Conductors: Solids, Membranes and Gels Materials and Devices, Chemistry of Solid State Materials, Vol. 2; Cambridge University Press: Cambridge, U.K., 1992. 